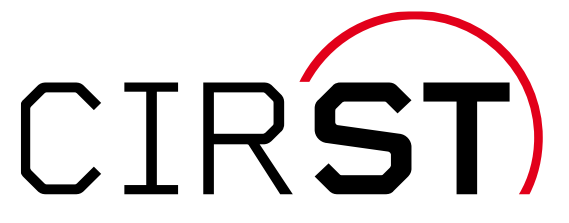

Centre interuniversitaire

de recherche sur la science

et la technologie

\title{
Artificial Intelligence in Quebec: A Tightly Knit Network
}

Maxime Colleret and Yves Gingras

U⿴囗十⺝M Université $\begin{gathered}\text { Unh } \\ \text { de Montréal }\end{gathered} \begin{gathered}\text { Fonds de recherche } \\ \text { société et culture } \\ \text { Québec }\end{gathered}$

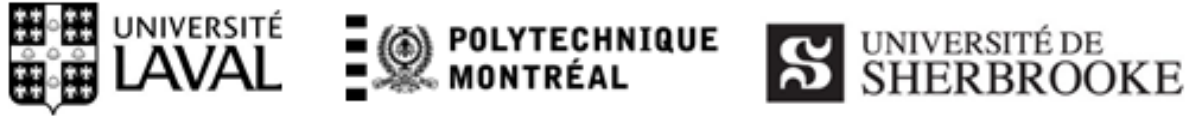




\section{Pour nous joindre}

Téléphone : 514.987-4018

Adresse électronique : cirst@uqam.ca

site : www.cirst.uqam.ca

Adresse postale

CIRST

Université du Québec à Montréal

C.P. 8888, succ. Centre-ville

Montréal (Québec)

H3C 3P8
Adresse civique

CIRST

$8^{e}$ étage

Université du Québec à Montréal

Pavillon Paul-Gérin-Lajoie

1205, rue Saint-Denis

Montréal, Québec 


\section{Biographical notes}

Maxime Colleret is a $\mathrm{PhD}$ candidate in Science, Technology and Society at UQAM and a student member of the Centre interuniversitaire de recherche sur la science et la technologie (CIRST). He has published several papers on the history of universities in Canada, particularly about technology transfer, and explores the promises of nanotechnologies and artificial intelligence in several forthcoming articles.

Yves Gingras is a Professor in the Department of History at UQAM, Scientific Director of the Observatoire des sciences et des technologies (OST) and a regular member of the Centre interuniversitaire de recherche sur la science et la technologie (CIRST). He has published numerous books, the most recent of which are, Histoire des sciences (Presses universitaires de France, 2018), Sociologie des sciences (Presses universitaires de France, 3rd edition, 2020), L'impossible dialogue. Sciences et religions (Boréal \& Presses universitaires de France, 2016); Science and Religion. An impossible dialogue (Polity Press, 2017); Les dérives de l'évaluation de la recherche. Du bon usage de la bibliométrie (Raisons d'agir Éditions, 2014); Bibliometrics and Research Evaluation. Uses and Abuses, (MIT Press, 2016). He also edited the collective Controverses: accords et désaccords en sciences humaines et sociales (CNRS Éditions, 2014).

\section{Acknowledgements}

We would like to thank Lisiane Lomazzi and Myriam Lavoie-Moore of the Groupe de recherche sur l'information et la surveillance au quotidien (GRISQ) for sharing a draft version of their research report Portrait de l'écosystème de l'intelligence artificielle au Québec. Your work gave us the initial impulse to undertake this research. We would also like to thank Daniel Letendre and Martine Foisy for their comments and suggestions on a preliminary version of this text. Our gratitude also goes to Louis Renaud-Desjardins of the Bureau des initiatives numériques (BIN) and Raouf Moncef Belbahar for their help with the data presented in the various figures of this note.

\section{Abstract}

Who are the key actors of artificial intelligence (AI) in Quebec? What are the links between the different organizations that constitute the AI research infrastructure? How have academia, politics and economics intermingled in the development of this infrastructure? Based on what promises did the Quebec and Canadian governments invest hundreds of millions of public funds in this infrastructure? This research note attempts to answer these questions. After briefly describing the AI research infrastructure and tracing the extent of public investment, we show how a small number of actors have positioned themselves so as to control the direction of most taxpayer-funded AI initiatives.

This research note is a translation of : Maxime Colleret and Yves Gingras (2020). L'intelligence artificielle au Québec : un réseau tricoté serré. Montréal: Centre interuniversitaire de recherche sur la science et la technologie, Note de recherche 2020-07. 
INTRODUCTION

1. RESEARCH INFRASTRUCTURE AND FUNDING __ 2

1.1 IVADO and IVADO Labs___ 3

1.2 Mila __ 4

1.3 Scale AI, Canada's AI Supercluster ___ 6

1.4 Other Government AI Initiatives and Funding ___ 9

1.5 Tax credits and organizational opacity 12

2. A DEVELOPMENT CONTROLLED BY A HANDFUL OF ACTORS __ 14

2.1 A tightly knit network _ 15

$2.2 \quad$ Betting everything on one horse __ 25

2.3 An influential and interested advisor _ 32

CONCLUSION: THE LIMITS OF RESOURCE CONCENTRATION __ 35 


\section{Introduction}

Artificial intelligence (AI) has been on everyone's lips for the past few years: politicians, academics, entrepreneurs, journalists, filmmakers, and enthusiasts of ever "new" technologies. Billions of dollars are being invested worldwide by governments in a kind of race against time to secure a hypothetical advantage "in the face of international competition"1. AI effectively takes advantage of a hyperbolic craze to carve out a place for itself at the center of governmental and industrial considerations. Canada and Quebec have not escaped this trend. The Quebec government alone announced in its 2019-2020 fiscal budget investments of more than $\$ 329$ million over 5 years to ensure the development and adoption of this technology ${ }^{2}$. Presented as the centerpiece of the next "industrial revolution"”, AI is currently driven by an enthusiasm characteristic of technological promises that follow one another decade after decade without delivering most of the results announced with great confidence and fanfare by complicit or naive media.

This research report proposes to go beyond the surface of things by analyzing more coldly how a research policy on AI was quickly implemented in Quebec, essentially based on the recurring rhetoric of "technological gap" and on the naive acceptance of speeches promising that Quebec could become a "world leader" in this field assured of a bright future for the benefit of all. For observers of technological promises conveyed by researchers seeking budgets, the current excitement, which is costly in terms of public funds, is not very original ${ }^{4}$

\footnotetext{
${ }^{1}$ Comité d'orientation de la grappe en intelligence artificielle, Stratégie pour l'essor de l'écosystème québécois en intelligence artificielle, Économie, science et innovation Québec, 2018, p. 12.

2 Québec, Vos priorités Votre Budget: plan budgétaire 2019-2020, Québec, Bibliothèque et Archives nationales du Québec, March 21, 2019, p. D37-D41; our translation.

${ }^{3}$ Joshua Bengio, "The Rise of Artificial Intelligence through Deep Learning", TEDx Montreal, 2017.

${ }^{4}$ For more information, see among others Mads Borup, Nik Brown, Kornelia Konrad \& Harro Van Lente, "The Sociology of Expectations in Science and Technology", Technology Analysis \& Strategic Management, vol. 18, no. 3/4, 2006, p. 285-298; Nik Brown, Brian Rappert \& Andrew Webster (dir.), Contested Futures, New York, Routledge, 2016; Sjoerd Bakker \& Björn Budde, "Technological hype and disappointment: lessons from the hydrogen and fuel cell case", Technology Analysis \& Strategic Management, vol. 24, no. 6, 2012, p. 549563; Monika Gislera, Didier Sornettea \& Ryan Woodard, "Innovation as a social bubble: The example of the Human Genome Project", Research Policy, vol. 40, 2001, p. 1412-1245; Harro Van Lente et al., "Comparing technological hype cycles: Towards a theory", Technological Forecasting \& Social Change, no. 80, 2013, p. $1615-1628$
} 
and merely follows the model previously deployed by nanotechnology promoters, although on a larger scale ${ }^{5}$.

\section{Research infrastructure and funding}

In order to analyze the way Quebec has followed this hype, we identify the main actors who first contributed to increase the popularity of AI among elected officials and who then "naturally" became the managers of the hundreds of millions of dollars that Quebec and Ottawa decided to "invest" in the announced "fourth industrial revolution".

In just a few years, Quebec and Ottawa have created or participated in the creation of numerous entities all dedicated to the promotion of AI: AI Policy Committee, Advisory Council, IVADO and Mila Institutes, IVADO Labs, more than 30 research chairs and, finally, the "super cluster" Scale AI. They have also supported the NextAI and Creative Destruction Lab programs, Prompt-Québec's collaborative projects, and offered tax credits to industry to stimulate their adoption of AI.

In the following pages, we first provide a brief portrait of government initiatives, focusing on the creation of Quebec's four main research and technology transfer organizations: IVADO, IVADO Labs, Mila and Scale AI. We then show that the development of AI is concentrated in the hands of a small number of researchers and entrepreneurs, who make hyperbolic promises, advise the government and benefit from the development of artificial intelligence, both monetarily and symbolically.

\footnotetext{
${ }^{5}$ Céline Lafontaine, Nanotechnologies et société : enjeux et perspectives : entretiens avec des chercheurs, Montréal, Boréal, 2010; Céline Lafontaine, «Le Québec Nanotech : les discours publics en matière de nanotechnologie entre promotion et fascination », Quaderni, no. 61, 2006, p. 39-53; David M. Berube, Nanohype, Prometheus Books, 2006; Bernadette Bensaude-Vincent; Jonathan Simon «Introduction. Nanotechnoscience: The End of the Beginning", Philosophia Scientice, vol. 23, no. 1, 2019, p. 5-17; Bernadette Bensaude-Vincent, "Nanotechnologies: une révolution annoncée", S.E.R. Études, Tome 411, p. 605-616; Patrick W. McCray, «Will Small be Beautiful? Making Policies for our Nanotech Future », History and Technology, vol. 21, no. 2, 2005, p. 177-203.
} 


\subsection{IVADO and IVADO Labs}

In Canada, the first major initiative towards the development of research infrastructures came in 2014, when Finance Minister James M. Flaherty announced the creation of the Canada First Research Excellence Fund (Apogee), which he intended to fund "to the extent of $\$ 1.5$

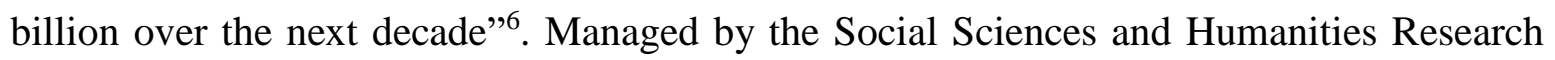
Council of Canada (SSHRC) on behalf of all the granting councils (NSERC, CIHR, SSHRC), this new fund was responsible for creating competition opened to academic institutions for grants in specific scientific fields.

Encouraged by a Western context favorable to AI, exemplified by the Information and Communications Technology Council of Canada's invitation "to act to prepare the future of the AI ecosystem in Canada" "7 the University of Montreal (UdeM) joined forces with HEC and Polytechnique under the label "Campus Montréal" and submitted the project Data Serving Canadians: Deep Learning and Optimization for the Knowledge Revolution. This project, based on the rhetoric of "revolution", was selected by the Apogee program, which awarded it more than $\$ 93$ million $^{8}$. With this funding, UdeM, Polytechnique and HEC established the IVADO research institute, to which the non-profit organization (NPO) IVADO Labs, chaired by Hélène Desmarais ${ }^{9}$, was added in October 2017. As stated on its website, "IVADO Labs was launched in 2017 with the significant contribution of the Quebec government in partnership with IVADO and its founding academic institutions" 10 .

Specializing in data management and optimization and emphasizing its pivotal position as a link between academia and industry, IVADO Labs quickly attracted the attention of the Quebec government. In March 2019, following its first electoral victory, the government of

\footnotetext{
6 James M. Flaherty, Plan budgétaire 2014, Sur la voie de l'équilibre : créer des emplois et des opportunités, Government of Canada, p. 131, our translation.

${ }^{7}$ Conseil des technologies de l'information et des communications, L'intelligence artificielle au Canada, où en sommes-nous?, 2015, p. 10; our translation.

8 Fonds d'excellence en recherche Apogée Canada, «Financement accordé », 2016. https://www.canada.ca/fr/innovation-sciences-developpement-economique/nouvelles/2016/09/fondsexcellence-recherche-apogee-canada.html

${ }^{9}$ Registre des entreprises du Québec, «IVADO Labs », information as of 2019-06-27.

${ }^{10}$ IVADO Labs, «IVADO Labs et l'écosystème IA de Montréal ». https://ivadolabs.com/fr/a-propos-de-nous/; our translation.
} 
the Coalition avenir Québec (CAQ) gave it its support. Picking up on the rhetoric of AI promoters and emphasizing the "transfer of expertise to companies", Quebec announced \$35 million in funding to IVADO Labs, effective in 2019-2020, "for the implementation of projects in all industrial sectors" "11. A few months earlier, the Fonds de recherche du Québec (FRQ) supported IVADO by providing money for the creation of three FRQ-IVADO Research Chairs, which individually received funding of five hundred thousand dollars over a period of 5 years $^{12}$. In just two years, IVADO and IVADO Labs were thus offered a total of nearly $\$ 130$ million from the Canadian and Quebec governments - most of this funding running over a 5-year period.

\subsection{Mila}

In 2017, in parallel to the creation of IVADO and IVADO Labs, the Quebec government allocated \$100 million to support the development of AI in Montreal. It then established the Comité d'orientation de la grappe en intelligence artificielle (COGIA), an advisory council co-presided by Guy Breton, then Rector of the University of Montreal, and Pierre Boivin, CEO of the investment company Claridge Inc. In 2018, the COGIA published the Stratégie pour l'essor de l'écosystème québécois en intelligence artificielle (Strategy for the Development of Quebec's Artificial Intelligence Ecosystem). In this document, it recommended that the government invest $\$ 80$ million over 5 years to support the creation and operation of Mila (Montreal Institute for Learning Algorithm). As recommended by the COGIA, this new institute, also transformed into an opaque $\mathrm{NPO}^{13}$, was then put in charge of implementing the strategy for the development of AI in Montreal. The government thus hoped to create an AI research pole that - like IVADO and IVADO Labs - would have strong links with industry with the ultimate goal of attracting technology companies to Montreal.

11 Québec, Vos priorités Votre Budget: plan budgétaire 2019-2020, Québec, Bibliothèque et Archives nationales du Québec, March 21, 2019, p. D.40; our translation.

${ }^{12}$ FRQ, « Nomination de trois titulaires de Chaires de recherche FRQ-IVADO pour la diversité et l'équité en science des données », April 17, 2019, 4 p. http://www.frqs.gouv.qc.ca/espace-presse/nouvelles-etcommuniques/nouvelle?id=vwnr6ljv1555522717357

${ }^{13}$ Formerly a standard academic research center specializing in "deep learning" at UofM, Mila acquired NPO status in 2017. 
Officially inaugurated in its offices of the O-Mile-Ex complex on the 28th of January 2019, Mila quickly became one of the main beneficiaries of state funding for artificial intelligence. At the provincial level, the Liberal government announced in 2017 an investment of approximately $\$ 100$ million over a 5-year period. Its successor, the CAQ government, has confirmed this decision ${ }^{14}$. In March 2019, it therefore committed a sum of $\$ 32.5$ million $^{15}$. At the federal level, Mila funding is channeled through CIFAR, another NPO dedicated to the "advancement of research". Interested in artificial intelligence since the 1980s, this organization - funded mostly by the federal government and to a lesser extent by Facebook and Royal Bank of Canada (RBC) - is responsible for administering the \$125 million funding of the Pan-Canadian AI Strategy announced in $2017^{16}$. Of this $\$ 125$ million, Mila was allocated $\$ 44$ million $^{17}$; the remaining $\$ 81$ million was divided between the University of Toronto's Vector Institute - led by Geoffrey Hinton, the Toronto-based counterpart of Yoshua Bengio who heads Mila - and the University of Alberta's Alberta Machine Intelligence Institute (Amii). With this funding, Mila's researchers were awarded 20 research chairs in $2018^{18}$. Of these, several "professors" are actually working for multinational technology companies such as Facebook, Microsoft and Google. It may seem curious that part of the public funds in AI seems to be used to support research in some of the richest companies in the world in terms of market capitalization ${ }^{19}$. Table 1 shows the occupations, affiliations and reasons given for granting a research chair, either "hiring" or "retention", suggesting the possibility of a "brain drain", an argument that is frequent, but often unverifiable in practice.

\footnotetext{
${ }^{14}$ This is what Radio-Canada reported at the moment of the inauguration of the Mila. See La Presse canadienne, «L'intelligence artificielle a désormais son quartier général à Montréal », Radio Canada, January 28, 2019. https://ici.radio-canada.ca/nouvelle/1149534/mila-intelligence-artificielle-montreal-institut-inauguration.

${ }^{15}$ Québec, Vos priorités Votre Budget..., op.cit., p. D.41.

${ }^{16}$ Government of Canada, Bâtir un classe moyenne forte, budget 2017, March 22, 2017, p. 117.

17 "Quebec AI institute Mila opens giant new facility in Montreal”, Re\$earch money, vol. 33, no. 2, January 28, 2019. https://researchmoneyinc.com/articles/quebec-ai-institute-mila-opens-giant-new-facility-inmontreal/

${ }^{18}$ Of the $\$ 125$ million allocated to CIFAR to administer the Pan-Canadian AI Strategy, $\$ 88.5$ million went toward the creation of some 40 research chairs across Canada. CIFAR, IACan 2019: Rapport annuel de la Stratégie pancanadienne en matière d'intelligence artificielle, 2019, p. 1-21.

${ }^{19}$ Dominic Martin, « Frankenstein $2.0 »$ in Régis, K. Benyekhlef et D. Weinstock (Ed.), Sauvons la justice!, Montréal, Del Busson Éditeur, 2017, p. 109-114.
} 
Regardless of the precise use of the funds, they bring the total public funding announced for Mila to $\$ 144$ million since its incorporation in the summer of 2017 by UdeM, McGill, Polytechnique and HEC. Most of this funding will be distributed over five years.

Table 1. Academic and industrial researchers affiliated to Mila who obtained a CIFAR research chair in AI in 2018-201920

\begin{tabular}{|c|c|c|c|c|}
\hline Researcher's name & $\begin{array}{l}\text { Academic } \\
\text { Affiliation }\end{array}$ & Academic position & $\begin{array}{c}\text { Industrial } \\
\text { Affiliations }{ }^{21}\end{array}$ & CIFAR's objective \\
\hline Marc G. Bellemare & McGill & Adjunct Professor & Google Brain & Hiring \\
\hline Yosgua Bengio & UdeM & Professor & Element AI & Retention \\
\hline Laurent Charlin & HEC & Assistant Professor & & Retention \\
\hline Jackie Cheung & McGill & Assistant Professor & & Retention \\
\hline Aaron Courville & UdeM & Associate professor & & Retention \\
\hline Geoffrey J. Gordon & Carnegie Mellon & Professor & Microsoft & Hiring \\
\hline William Hamilton & McGill & Assistant Professor & & Hiring \\
\hline $\begin{array}{c}\text { Simon Lacoste- } \\
\text { Julien }\end{array}$ & UdeM & Associate professor & Samsung & Retention \\
\hline Hugo Larochelle & UdeM & Adjunct Professor & Google Brain & Retention \\
\hline Ioannis Mitliagkas & UdeM & Associate professor & & Hiring \\
\hline Christopher Pal & Polytechnique & Professor & Element AI & Retention \\
\hline Liam Paull & UdeM & Assistant professor & & Hiring \\
\hline Joëlle Pineau & McGill & Associate professor & Facebook & Retention \\
\hline Doina Precup & McGill & Associate professor & Google DeepMind & Retention \\
\hline Reihaneh Rabbany & McGill & Assistant professor & & Hiring \\
\hline $\begin{array}{l}\text { Guillaume } \\
\text { Rabusseau }\end{array}$ & UdeM & Assistant professor & & Hiring \\
\hline Blake Richards & McGill & Assistant professor & & Retention \\
\hline Jian Tang & HEC & Assistant professor & & Hiring \\
\hline Pascal Vincent & UdeM & Associate professor & Facebook & Retention \\
\hline Frank Wood & UBC & Associate professor & & Hiring \\
\hline
\end{tabular}

\subsection{Scale Al, Canada's Al Supercluster}

In the 2016 federal budget, the Liberal government proposed "to make available up to $\$ 800$ million over four years to support innovation networks and clusters"22. A year later, a competition for the creation of innovation "superclusters" was announced. According to the

\footnotetext{
${ }^{20}$ Affiliations at the time of the announcement.

${ }^{21}$ Excluding periodic consultation activities.

${ }^{22}$ Government of Canada, Plan budgétaire 2016 : Assurer la croissance de la classe moyenne, March 22, 2016, p. 135 .
} 
government, these "superclusters" should support "clusters" 23 that "have the greatest potential to accelerate economic growth" 24 . Specifically, they should facilitate universityindustry-government collaboration ${ }^{25}$, allow for greater sharing of risk between member organizations - in terms of technology development -, further integrate "supply chains" and provide "advisory services" and "mentoring" to small and medium-sized enterprises (SMEs). In addition to the $\$ 800$ million announced in this budget, the Liberals also announced an investment of $\$ 150$ million coming from the "public transit and green infrastructure funds", totalling $\$ 950$ million for the creation of a few “superclusters" 26 .

To distribute the funds, the Innovation Supercluster Initiative (ISI) was created. It launched a competition in 2017 and asked "industry-led consortia" to submit applications, which had to demonstrate seriousness through a commitment from the private sector to match the government's investment ${ }^{27}$. In order to link universities (research and training) with private actors, the ISI required the presence of at least one university - which was not expected to match the government's investment - in the consortia ${ }^{28}$.

Five projects across Canada were selected. In Quebec, Canada's AI Supercluster (Scale AI) was awarded $\$ 230$ million in funding from Ottawa. It aims to bring together the retail, manufacturing, transportation, infrastructure, information, and communications technology sectors $^{29}$ to create and optimize supply chains using artificial intelligence ${ }^{30}$.

${ }^{23}$ Ottawa describes these "clusters" as "areas of high commercial density that bring together businesses of all sizes, post-secondary institutions as well as specialized infrastructure and talent." [Traduction] Voir Government of Canada, Plan budgétaire 2017 : Bâtir une classe moyenne forte, March 22, 2017, p. 89.

${ }^{24}$ Ibid.

${ }^{25}$ This is nothing new or surprising in itself. The close collaboration between these three actors is constantly promoted in the discourse of technological innovation. See for example Henry Etzkowitz, et Loet Leydesdorff, "The triple Helix - University-Industry-Government relations: A Laboratory for Knowledge Based Economy Development", EASST Review 14, no. 1 (1995): 14-19.

${ }^{26}$ Government of Canada, Plan budgétaire 2017 ..., op.cit., p. 89-90.

${ }^{27}$ Government of Canada, Supergrappes d'innovation: guide de programme, 2017, p. 4.

${ }^{28}$ Ibid., p. 5.

${ }^{29}$ Government of Canada, Supergrappe de chaînes d'approvisionnement axées sur l'IA (SCALE AI), https://www.ic.gc.ca/eic/site/093.nsf/fra/00009.html.

${ }^{30}$ The use of artificial intelligence in supply chains is often presented by AI enthusiasts as an effective way to increase productivity and reduce business costs, particularly by facilitating inventory control and planning, procurement planning and demand management. See for example Hokey Min, « Artificial intelligence in supply 
Consistent with the ambition of AI promoters to increasingly put universities at the service of businesses, Dominique Anglade, then Minister of Economy, Science and Innovation and Minister responsible for the Digital Strategy of Quebec, reacted to the success of Scale AI's application by stating that it "will ensure the collaborations between businesses, universities, research and innovation centers and startups, both nationally and internationally" 31 . Convinced by the potential of AI, the Liberal government of Quebec in turn announced an investment of $\$ 60$ million over 5 years in its 2018 budget to support the "supercluster" - the first payment of $\$ 20$ million was made in December $2018^{32}$. One year later, the new caquist government chose to respect this commitment by granting $\$ 23.4$ million $^{33}$, which brings the public funding announced for Scale AI to \$290 million since its foundation.

Scale AI is a consortium of Canadian companies, Quebec and Ontario universities (Concordia, Waterloo, Laval, McGill, HEC Montreal, University of Toronto, etc.), and NPOs (such as NextAI), which link companies and academic institutions in order, as hoped, to accelerate the adoption of AI products in the industrial sector. It entered its "operational phase" in June 2019 with the announcement of four collaborative projects for a total of $\$ 5.1$ million - \$2 million of which comes from Scale AI. Of these four projects, two involve IVADO Labs, which will collaborate with the logistics company Ray-Mont and the engineering firm SimWell, to develop a "decision support system for operations planning,

chain management: theory and applications », International Journal of Logistics: Research and Applications, vol. 13, no. 1, 2010, p. 13-39.

${ }^{31}$ Dominique Anglade, quoted in Government of Quebec, « Supergrappes technologiques - Québec accueille favorablement la sélection du projet de Scale AI», Press release, February 15, 2018. http://www.filinformation.gouv.qc.ca/Pages/Article.aspx?idArticle=2602158874\&lang=en.

32 Government of Quebec, «60 M\$ pour soutenir les activités de la supergrappe des chaînes d'approvisionnement intelligentes », Press release, December 6, 2018. https://www.economie.gouv.qc.ca/ministere/salle-de-presse/communiques-de-presse/communique-depresse/?no_cache=1\&tx_ttnews\%5Btt_news\%5D=23139\&cHash=2e2246ed26749e9bf7a49e1931ec4846.

${ }^{33}$ Scale AI, «Le gouvernement du Québec octroie 23,4 M \$ à Scale AI pour le développement de talents en intelligence artificielle », Press release, July 15 2019, p. 1-2. https://www.scaleai.ca/fr/le-gouvernement-duquebec-octroie-234-m-a-scale-ai-pour-le-developpement-de-talents-en-ia/ 
storage allocation and crane scheduling". IVADO Labs will also work with Bell Canada and its partners on "predicting the complexity of field repairs and technician management" ${ }^{\text {" }}$.

\subsection{Other Government Al Initiatives and Funding}

As if IVADO, IVADO Labs, Mila and Scale AI were not enough, the Quebec government also invested in smaller initiatives such as Creative Destruction Lab (CDL) and NextAi support programs. In the March 2018 budget, the then Liberal government announced that it would support these two programs with $\$ 10$ million - $\$ 5$ million per program - over five years. Based at HEC, these programs are intended to help academics launch spinoff companies through mentoring and venture capital funding. Consistent with its ambition to better integrate the academic sphere with the industrial sector through AI, the government was attracted by this technology transfer function. When the Liberals announced their intention to fund these programs, they stressed that the CDL (and NextAi) was "particularly well suited to early-stage companies associated with university labs" ${ }^{\prime 5}$. It was the same motivation that prompted the CAQ government to subsidize Prompt-Québec in 2019, a university-industry liaison organization. Specialized in information and communication technologies (ICT), Prompt-Québec acts as a bridge between public research centers and businesses. To support its activities in the field of artificial intelligence, the government made available $\$ 17.5$ million in its 2019 budget.

The first budget of the caquist government is the most ambitious to date in favor of $\mathrm{AI}$ in Quebec. While the previous year, the Liberal government had promised more than one hundred million dollars in funding over a 5-year period, its electoral defeat nullified these promises. Elected with a majority in October 2018, the CAQ continued in the direction established by its predecessor and, in its first budget, promised more than $\$ 329$ million over five years (Table 2).

\footnotetext{
${ }^{34}$ Scale AI, «Scale AI annonce la sélection de projets novateurs en intelligence artificielle appliquée aux chaînes d'approvisionnement », Press release, June 27, 2019, 2p; our translation.

${ }^{35}$ Government of Quebec, Le plan économique du Québec, Bibliothèque et Archives nationales du Québec, March 27, 2018, p. D23; our translation.
} 
As shown in Table 2, government initiatives announced in Quebec for AI since 2016 amount to a minimum of $\$ 960.3$ million $^{36}$, more than half of which is for IVADO, IVADO Labs Mila and Scale AI. The latter are the government's primary focus for artificial intelligence. And it is likely that they will also benefit from the funding announced, but not detailed, in the 20192020 budget - think of the proposed funds for expanding the training offer, attracting researchers and the adoption of $\mathrm{AI}$ in businesses, for example. By way of comparison, it should be noted that Mila, IVADO, IVADO Labs and Scale AI alone received just over $\$ 80$ million in public funds from the Quebec government in 2019, about \$20 million more than the total budget of the Fonds de recherche du Québec - Nature et technologie (FRQNT), an organization that funds all areas of research related to the natural sciences and engineering in Quebec. And that's not counting the approximately $\$ 130$ million invested that same year by the government and Caisse de dépôt et placement du Québec (CDPQ) in Element AI, a company specializing in AI co-founded by professor-entrepreneur Yoshua Bengio.

\footnotetext{
${ }^{36}$ For a study on AI funding in Quebec, see Lisiane Lomazzi, Myriam Lavoie-Moore \& Joëlle Gélinas, «Financer l'intelligence artificielle, quelles retombées économiques et sociales pour le Québec ? , Institut de recherche et d'information socio-économique (IRIS), March 2019. 
Table 2. Public funding announced for the development of AI in Quebec since 2016

\begin{tabular}{|c|c|c|c|c|}
\hline $\begin{array}{c}\text { Organizations/Initiative } \\
s \\
\text { beneficiaries of the } \\
\text { funding }\end{array}$ & $\begin{array}{c}\text { Year of } \\
\text { Funding } \\
\text { Announceme } \\
\text { nt }\end{array}$ & Provincial Funding & $\begin{array}{l}\text { Federal } \\
\text { Funding }\end{array}$ & $\begin{array}{c}\text { Amount } \\
\text { announced }\end{array}$ \\
\hline IVADO/IVADO Labs ${ }^{37}$ & 2016 & & Apogee Canada & $\begin{array}{c}93 \mathrm{M} \$ / 7 \\
\text { years }\end{array}$ \\
\hline IVADO Labs & 2019 & Budget 2019 & & $\begin{array}{c}35 \mathrm{M} \$ / 1 \\
\text { year }\end{array}$ \\
\hline IVADO & 2019 & FRQ & & $\begin{array}{c}1.5 \mathrm{M} \$ / 5 \\
\text { years }\end{array}$ \\
\hline $\begin{array}{c}\text { Total IVADO/IVADO } \\
\text { Labs } \\
\end{array}$ & & & & $129.5 \mathrm{M} \$$ \\
\hline Mila $^{38}$ & 2017 & Budget 2017 & & $\begin{array}{c}100 \mathrm{M} \$ / 5 \\
\text { years }\end{array}$ \\
\hline Mila & 2017 & & CIFAR & $\begin{array}{c}44 \mathrm{M} \$ / 1 \\
\text { year }\end{array}$ \\
\hline Total Mila & & & & $144 \mathrm{M} \$$ \\
\hline Scale AI & 2017 & & $\begin{array}{l}\text { Innovation } \\
\text { Supercluster } \\
\text { Initiative }\end{array}$ & $\begin{array}{c}230 \mathrm{M} \$ / 1 \\
\text { year }\end{array}$ \\
\hline Scale AI & 2018 & Budget 2018 & & $\begin{array}{c}60 \mathrm{M} \$ / 3 \\
\text { years }\end{array}$ \\
\hline Total Scale AI & & & & $290 \mathrm{M} \$$ \\
\hline $\begin{array}{c}\text { Creative Destruction } \\
\text { Lab }\end{array}$ & 2018 & Budget 2018 & & $5 \mathrm{M} \$ / 5$ years \\
\hline NextAI & 2018 & Budget 2018 & & $5 \mathrm{M} \$ / 5$ years \\
\hline Prompt-Québec & 2019 & Budget 2019 & & $\begin{array}{c}17.5 \mathrm{M} \$ / 1 \\
\text { year }\end{array}$ \\
\hline $\begin{array}{c}\text { Expanding the } \\
\text { availability of AI } \\
\text { training }\end{array}$ & 2019 & Budget 2019 & & $\begin{array}{c}12.5 \mathrm{M} \$ / 5 \\
\text { years }\end{array}$ \\
\hline $\begin{array}{c}\text { Attraction of } \\
\text { researchers }\end{array}$ & 2019 & Budget 2019 & & $\begin{array}{c}38 \mathrm{M} \$ / 5 \\
\text { years }\end{array}$ \\
\hline $\begin{array}{c}\text { Adoption of AI in } \\
\text { companies }\end{array}$ & 2019 & Budget 2019 & & $\begin{array}{c}65 \mathrm{M} \$ / 5 \\
\text { years }\end{array}$ \\
\hline $\begin{array}{c}\text { Increase in computing } \\
\text { power }\end{array}$ & 2019 & Budget 2019 & & $\begin{array}{c}34.5 \mathrm{M} \$ / 5 \\
\text { years }\end{array}$ \\
\hline $\begin{array}{l}\text { Technology in support } \\
\text { of AI }\end{array}$ & 2019 & Budget 2019 & & $\begin{array}{c}79.3 \mathrm{M} \$ / 5 \\
\text { years }\end{array}$ \\
\hline Element $\mathbf{A I}^{39}$ & 2018 & & $\begin{array}{l}\text { Federal } \\
\text { Funding }\end{array}$ & $5 \mathrm{M} \$$ (loan) \\
\hline
\end{tabular}

${ }^{37}$ On its website, IVADO Labs claims to be funded by the Apogee Canada Fund, as IVADO itself. It seems that the $\$ 93$ million in funding from the federal government is thus shared, at least in part, between the two entities. In the absence of financial reports published by IVADO Labs, it is difficult to determine if this is indeed the case. We come back on the issue of financial reports below.

38 The CAQ government has confirmed to Radio-Canada that it will respect this budget envelope. Thus, the $\$ 32.5$ million in funding for Mila announced in the 2019-2020 budget is not in addition to the $\$ 100$ million announced by the QLP a few years earlier. It is part of it. La Presse canadienne, «L'intelligence artificielle a désormais... », loc.cit.

${ }^{39}$ Element AI will be discussed below. 


\begin{tabular}{|c|c|c|c|c|}
\hline Element AI & 2019 & CPDQ & & $\begin{array}{c}99 . \mathrm{M}^{40} / 1 \\
\text { year }\end{array}$ \\
\hline Element AI & 2019 & Government support & $\begin{array}{c}33 . \mathbf{M}^{41} / 1 \\
\text { year }\end{array}$ \\
\hline Total Element AI & & & & $137 \mathrm{M} \$$ \\
\hline Imagia & 2018 & $\begin{array}{c}\text { BioMed Propulsion } \\
\text { Program }\end{array}$ & & $3 \mathrm{M} \$(\text { loan })^{42}$ \\
\hline Total & & & 960.3 & $\mathrm{M} \$$ \\
\hline
\end{tabular}

\subsection{Tax credits and organizational opacity}

In addition to this direct funding, AI also benefits from tax credits provided by the government. Since 1987, Quebec has effectively implemented a system of tax credits "to intensify collaboration between businesses and universities", benefiting companies that award research contracts to academic institutions or academic research centers. Three types of tax credits apply particularly - but not exclusively - to AI: one for R\&D, one for consortium research and one for the salaries of in-house researchers.

Thus, when a company awards a research contract to IVADO or Mila, it is entitled to a tax credit that varies between 14 and $30 \%$ of its expenses - according to different modalities. This partly explains why more than 80 companies are partners of IVADO and more than 25 are members of Mila. Highly integrated to the industrial sector, these organizations behave essentially as industrial research centers and correspond to what sociologists Sheila Slaughter and Larry Leslie describe as "academic capitalism". Founded by universities, but more interested in industries than academia, these centers use infrastructure and human resources from public budgets but adopt a market logic to obtain funding from outside academic

40 Sean Silcoff, "Element AI closes financing, securing \$200-million backed by the Caisse, Quebec and McKinsey", The Globe and Mail, September 13 ${ }^{\text {th }}, 2019$. https://www.theglobeandmail.com/business/articleelement-ai-closes-financing-securing-200-million-backed-by-the/

${ }^{41}$ Ibid.

42 BioMed Propulsion Program, «L'intelligence artificielle appliquée à l'oncologie : Québec accorde un prêt de 3 millions de dollars à Imagia », Press release, March 262018. https://www.economie.gouv.qc.ca/ministere/salle-de-presse/communiques-de-presse/communique-depresse/?no cache $=1 \& \mathrm{tx}$ ttnews $\% 5 \mathrm{Btt}$ news $\% 5 \mathrm{D}=22046$ 
institutions. Thus, IVADO defines itself by emphasizing its pivotal position between university and business to attract funds:

IVADO's mission is to be a bridge between industry professionals and academic researchers to develop cutting-edge expertise in the field of data science, artificial intelligence and operations research and to transform new scientific discoveries into concrete innovative applications, economic opportunities and benefits for society.

Mila also hopes to create "a unique space for innovation in artificial intelligence and technology transfer that will leverage interactions with industry and spark the emergence of start-ups while integrating the social impacts of technologies into its projects". Mila and IVADO are therefore banking on their academic credibility and their proximity to companies to obtain private funding and to reach agreements with "industry professionals" on the implementation of industrial research projects. In this way, they are fully participating in the strategy of commercialization of university research, which aims to compensate for the historical weakness of private investment in industrial research in Quebec.

In addition to the tax credit for university research, IA benefits from the credit for consortium research. This particularly concerns the members of Scale AI, an organization whose objective is to bring together companies to carry out "pre-competitive" research. Thus, besides benefiting from the equipment and services of Scale AI, abundantly financed by taxpayers, member companies are eligible for a tax credit, which also varies from 14 to $30 \%$, when they carry out research with Scale AI. Finally, AI companies can also deduct from 14 to $30 \%$ of the salary of an employee who devotes most of his time to research, which completes the picture of the main financial and tax assistance from the government in the field of artificial intelligence. Although all this is intended to serve businesses, the bulk of the budget comes from the public sector.

Moreover, it is difficult, if not virtually impossible for the moment, to analyze how public funds are being used by the NPOs established since 2017, such as Mila, IVADO Labs and Scale AI. Under the NPO Act adopted by the federal government in 2009, NPOs that engage in solicitation and receive more than $\$ 10,000$ from public sources in a fiscal year, must submit their financial reports to Corporations Canada. These are then made available to the public. Those requirements are specific to NPOs that use solicitation. As noted by 
Corporations Canada, since these organizations "receive public funds, they must meet additional requirements to ensure sufficient transparency and accountability for these revenues". At the time of this writing, however, only Mila had submitted a financial report to Corporations Canada since its inception. During the fiscal year ending March 31, 2019, Mila received approximately $\$ 14.5$ million from the Quebec and Canadian governments. On the other hand, this organization, claiming to be a hub for collaboration with industry, only received \$194,000 in "industry sponsorships" and \$264,000 in "research contracts" - note that the latter could also come from the public sector -, equivalent to barely $3 \%$ of the public funds invested.

For their part, IVADO Labs and Scale AI have to date (as of 07-01-2020) not submitted any financial reports to Corporations Canada since their founding in 2017, making it impossible to conduct a detailed review of the activities of these two taxpayer-funded organizations. According to the response obtained from the Ministère de l'Économie et de l'Innovation du Québec (MEI), following an access to information request, these documents have, nonetheless, been received by the MEI (which funds them in large part). But the MEI says it cannot "transmit these documents since they contain strategic commercial information belonging to the organizations", which is "protected under sections 23 and 24 of the Access to Information Act". The opacity of NPOs, even though they are "not-for-profit" is thus confirmed and the Ministry even added that they have "strategic commercial information". So, these NPOs are doing business, but without making money and using public funds, without the possibility for the public to know what they are really doing with this money.

\section{A development controlled by a handful of actors}

By gathering data available online on AI advisory boards and boards of directors of the most important research and technology transfer centers, we have mapped the network of the main AI stakeholders in Quebec, thus highlighting a "tightly knit" network of actors. It is striking that all the developments analyzed above are concentrated in the hands of a handful of researchers and "entrepreneurs" often positioned both as government advisors and beneficiaries of public funds. 
Indeed, the analysis of this network reveals that the Quebec AI infrastructure is steered by a small group of individuals who share several functions and who contribute directly or indirectly to linking different organizations together. Thus, businesswoman Hélène Desmarais simultaneously serves as president of the board of directors at IVADO Labs, Scale AI, CDL and HEC, which makes her one of the managers of more than $40 \%$ of government funds invested in AI infrastructure in Quebec ${ }^{43}$. In addition, many of the key actors in AI hold multiple positions and find themselves circulating in the economic, political and scientific fields at the same time ${ }^{44}$. They thus contribute to the organizational and ideological integration of these fields around a common objective: increasing investments in artificial intelligence - especially in the subset of AI techniques known as "machine learning".

\subsection{A tightly knit network}

In order to map the network of AI policy advisors and administrators of the research and technology transfer infrastructure, we used Gephi, an open access social network analysis and visualization software. Using the Force Atlas algorithm, we produced two figures. The first maps the links between organizations (IVADO Labs, Mila, Scale AI, CDL, COGIA, CCMIA, and the different branches of CIFAR), the strength of the links being stronger when several actors are simultaneously found within two organizations at the same time. In this figure, only the affiliations (companies, ministries, advisory councils or institutions) of administrators and policy advisors appear. The second figure maps the links between actors, the strength of the links between two actors being stronger when they simultaneously manage several organizations. In this figure, organizations are evacuated in favor of individuals and the links between them represent their co-presence on committees. This brings out the central actors of the artificial intelligence research and technology transfer infrastructure in Quebec.

\footnotetext{
43 Several AI stakeholders are concerned about the concentration of public funds in the hands of Hélène Desmarais; see for example Francis Halin, « Hélène Desmarais, la femme qui règne sur l'intelligence artificielle au Québec », Le Journal de Montréal, February 25, 2019; Idem, « Le tour de force d'Hélène Desmarais », Le Journal de Montréal, April 29, 2019.

44 Pierre Bourdieu, « Champ du pouvoir, champ intellectuel et habitus de classe », Scolies, vol.1, 1971, p. 726; Idem, «Le capital social », Actes de la recherche en sciences sociales, vol. 31, 1980, p. 2-3; Idem, «La spécificité du champ scientifique et les conditions sociales du progrès de la raison », Sociologie et sociétés, vol. 7, no. 1, 1975, p. 91-118.
} 
Considering Figure 1, the main research and technology transfer centers are strongly linked to each other at the administrative level. As illustrated by the density of green links, several members of IVADO, IVADO Labs, Mila, Scale AI and CDL simultaneously administer at least two research centers - note that we have merged IVADO Labs and IVADO in Figure 1 , even though they are officially two separate entities, their close links have led us to consider them as a single organization in our network. Hélène Desmarais is, for example, Chair of the Board of IVADO Labs, Chair of the CDL and Co-Chair of Scale AI. In addition, several directors of these organizations are members of the Comité d'orientation de la grappe en IA (COGIA), an advisory board responsible for advising the Quebec government on its policies and investments in AI. The latter, shown in blue to illustrate its role with the Quebec government, is therefore essentially composed of the managers of Quebec's AI research infrastructure. COGIA is thus completely integrated within this infrastructure, which, as we will see below, could be one of the factors explaining why its first report recommends investing such significant amounts of money in it.

The venture capital firm Inovia Capital and the artificial intelligence firm Element AI are also represented in the network. The former is represented in COGIA, the Creative Destruction Lab (CDL) and Mila. The latter is represented mainly through ProfessorEntrepreneur Yoshua Bengio, in COGIA, the Federal Government's Conseil consultatif en matière d'intelligence artificielle (CCMIA), Mila, IVADO, CDL, Scale AI and CIFAR, hence in every organization established thanks to public investments since 2016.

Federal entities, such as CCMIA and the various branches of CIFAR are more peripheral. Charged with advising the Government of Canada on its AI policies and shown in red to illustrate its position in Ottawa, the CCMIA is almost exclusively composed of representatives coming from technology companies that do not manage any Quebec's AI research centers. The various branches of CIFAR have relatively weak administrative links with Quebec research infrastructure: apart from a few actors, the majority of CIFAR members do not hold administrative positions in the organizations mentioned above. 
Figure 1. Links between organizations as of September 2019 according to the affiliations of their members

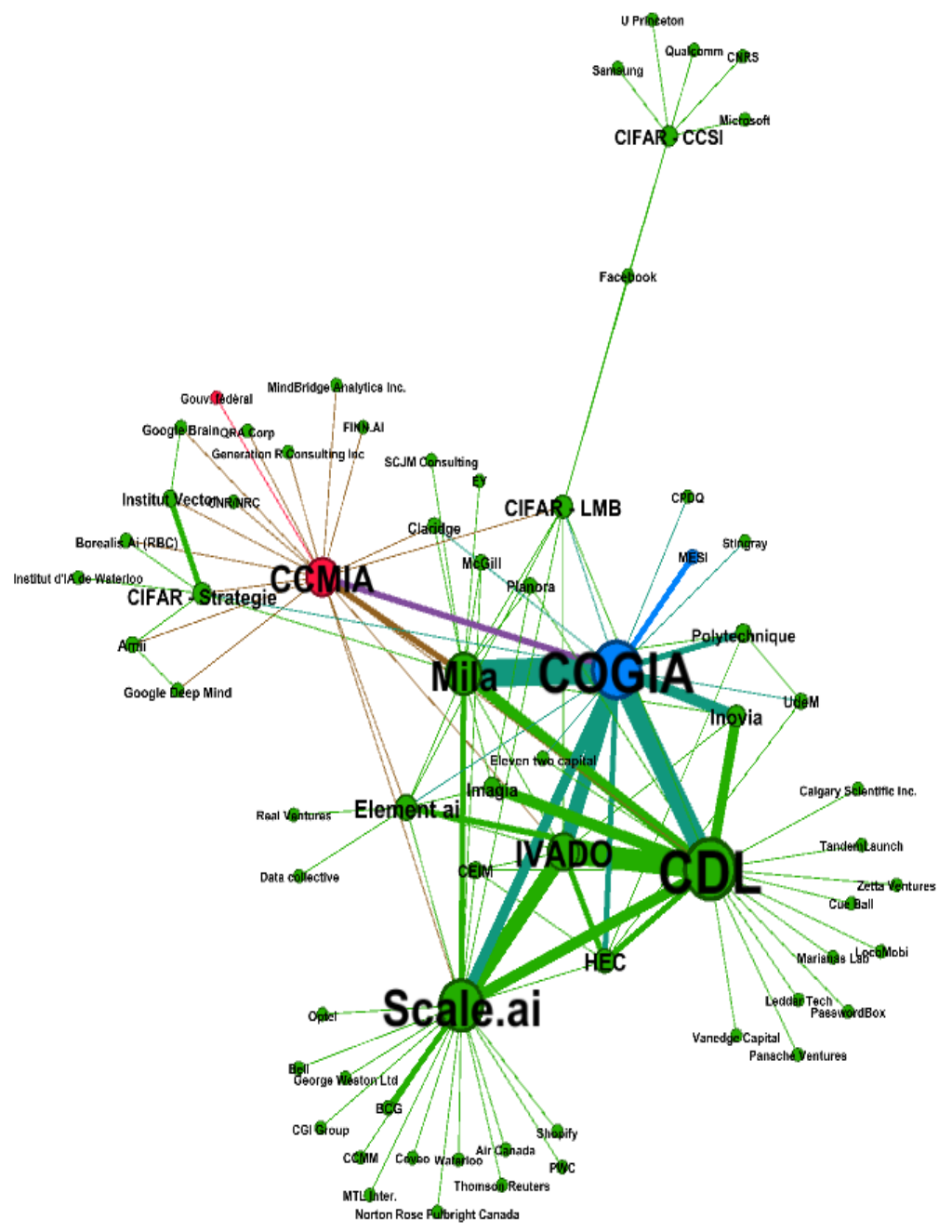

Let's now move from organizations to core stakeholders who are actively involved in the integration of AI research centers and advisory councils and who ensure liaison with more peripheral entities, such as CCMIA or CIFAR. 
Figure 2: Quebec Network of AI Administrators and Policy Advisors in September 2019

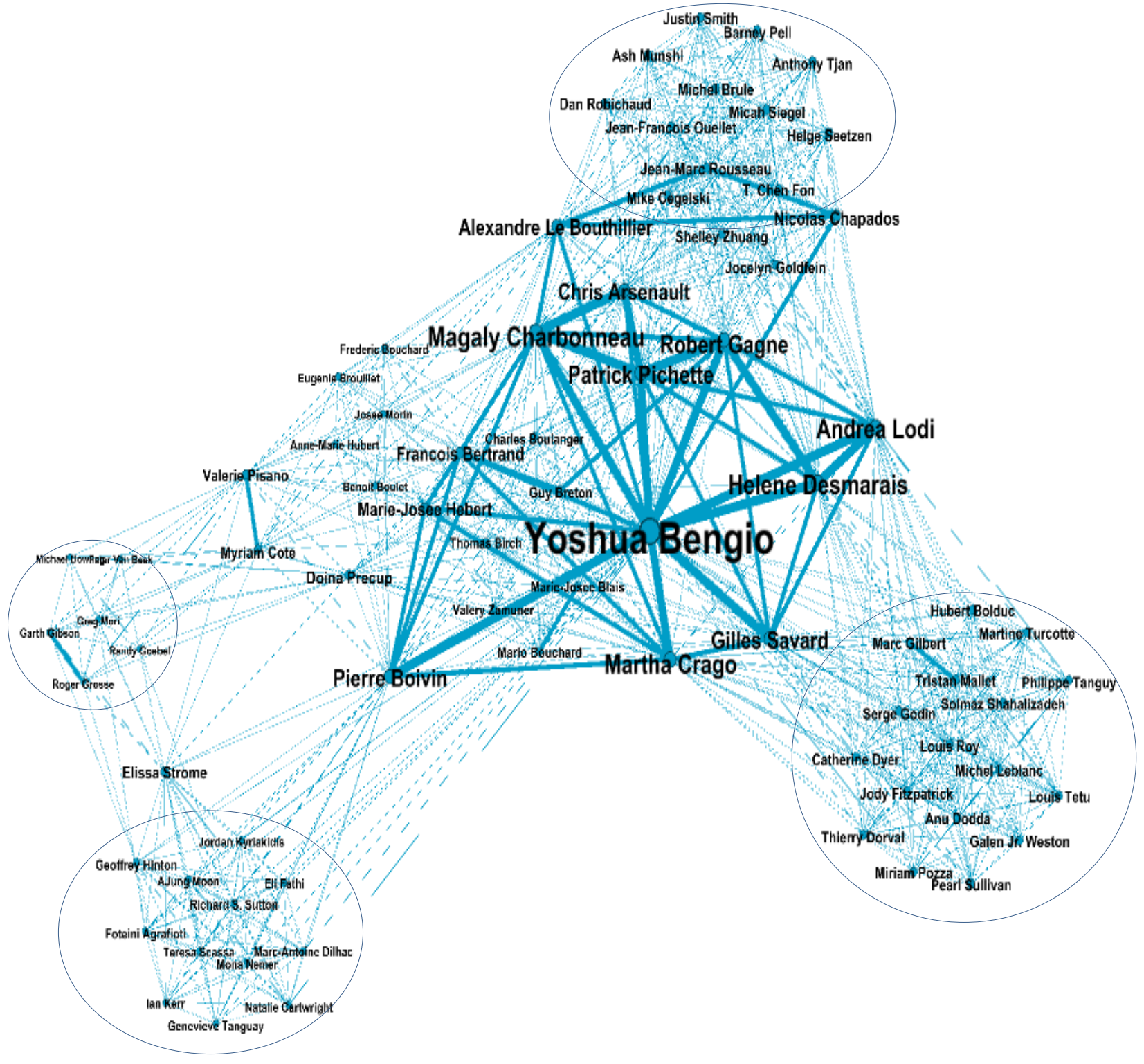


As shown in Figure 2, four clusters stand out in the overall structure of the network and are distributed around the central core where the leaders of Mila, IVADO Labs and those who advise the Quebec government within COGIA are found. These four groups are: 1) the members of CCMIA in the lower left corner, 2) those of CIFAR's Pan-Canadian Strategy a little higher up, 3) those of Scale AI in the lower right corner and 4) those of the CDL completely at the top. The actors who head Mila and IVADO Labs and who advise the Quebec government within COGIA are at the center of the network because they are the ones who link the different organizations together. These actors, whose links in bold show close proximity, constitute the core of the AI subsidized infrastructure in Quebec and therefore have the most influence regarding the orientation given to this infrastructure.

\section{Table 3. Degree of centrality in September 2019 of the top ten actors out of a possibility of $\mathbf{8 8}^{\mathbf{4 5}}$}

\begin{tabular}{|c|c|}
\hline Names & Degree of centrality \\
\hline Yoshua Bengio & $77 / 88$ \\
\hline Hélène Desmarais & $43 / 88$ \\
\hline Martha Crago & $43 / 88$ \\
\hline Andrea Lodi & $42 / 88$ \\
\hline Magaly Charbonneau & $41 / 88$ \\
\hline Pierre Boivin & $37 / 88$ \\
\hline Gilles Savard & $36 / 88$ \\
\hline Robert Gagné & $35 / 88$ \\
\hline Patrick Pichette & $35 / 88$ \\
\hline Chris Arseneault & $34 / 88$ \\
\hline
\end{tabular}

Out of a total network of 88 individuals (Table 3), professor-entrepreneur Yoshua Bengio is directly linked to 77 administrators or advisors, which makes him an inevitable passage point for all the less central actors and, as a result, the most influential person in AI in Quebec. Perhaps more surprisingly, this researcher, internationally recognized for his scientific contributions, is followed by Hélène Desmarais, linked to 43 people. As for Martha Crago, she owes her relative centrality to her position as Vice-Principal for Research and Innovation, and represents McGill University within Mila, Scale AI and COGIA.

\footnotetext{
${ }^{45}$ The degree of centrality is the number of links a node has with other nodes in the network.
} 
Other actors who appear more peripheral at first glance have a strong intermediarity and thus contribute to linking otherwise separate groups. This is the case of Doina Precup, Associate Professor at McGill, who acts as a bridge between COGIA (center of Figure 2) and the CIFAR Pan-Canadian Strategy (top left of Figure 2). This is also the case for Pierre Boivin, CEO of the investment firm Claridge, who is both among the most central actors, as shown in Figure 2, and among the actors who link COGIA to CCMIA - he co-chairs the former and is a member of the latter.

While Figure 2 shows a significant concentration of power within the Quebec AI network, it tells us little about the function of each actor, which limits the analysis that can be done on the effects of this concentration. To do so, we must refer to Table 4 on the multipositionality of the ten most central actors, a notion that better illustrates the organizational integration of the political, economic and academic fields. According to the sociologist Luc Boltanski, the multipositionality of a limited number of actors favors "the import of agents from one field to another, and thus the circulation of languages, ways of thinking, themes and questions". It thus contributes "to the production of common problems" and to "the work of integration" of a group "by producing a feeling of familiarity and solidarity among its members" Following this logic, the presence of the ten most central actors of AI in Quebec within the political, economic and academic fields contributes to the production of common goals among them. Their proximity to the political sphere (as advisors within COGIA, for example) suggests that they possess the necessary social capital to bring the State to intervene in their interests, since the latter relies on their expertise to intervene in AI.

\footnotetext{
${ }^{46}$ Luc Boltanski, «L'espace positionnel : multiplicité des positions institutionnelles et habitus de classe », Revue française de sociologie, vol. 14, no.1, 1973, p. 25. 
Table 4. Multipositionality of the most central actors of AI in Quebec in September 2019: presence or proximity in several social fields

\begin{tabular}{|c|c|c|c|}
\hline Names & Academic Field & Political Field & Economic Field \\
\hline Yoshua Bengio & $\mathrm{X}$ & $\mathrm{X}$ & $\mathrm{X}$ \\
\hline Hélène Desmarais & $\mathrm{X}$ & $\mathrm{X}$ & $\mathrm{X}$ \\
\hline Martha Crago & $\mathrm{X}$ & & $\mathrm{X}$ \\
\hline Andrea Lodi & $\mathrm{X}$ & $\mathrm{X}$ & $\mathrm{X}$ \\
\hline Magaly Charbonneau & $\mathrm{X}$ & $\mathrm{X}$ & $\mathrm{X}$ \\
\hline Pierre Boivin & $\mathrm{X}$ & $\mathrm{X}$ & $\mathrm{X}$ \\
\hline Gilles Savard & $\mathrm{X}$ & $\mathrm{X}$ & $\mathrm{X}$ \\
\hline Robert Gagné & $\mathrm{X}$ & $\mathrm{X}$ & $\mathrm{X}$ \\
\hline Patrick Pichette & & $\mathrm{X}$ & $\mathrm{X}$ \\
\hline Chris Arseneault & & & \\
\hline
\end{tabular}

In order to produce Table 4, we associated the position of actors with a field. Members of COGIA or CCMIA, were associated with the political field, since the federal and provincial governments rely on these advisory councils to implement their AI development policies. Members and managers of a research center, meant to be academic (IVADO and Mila), were associated with the academic field. Finally, managers technology-based companies or having an administrative position within Scale AI, IVADO Labs or the CDL (three entities entirely turned towards industry that make universities and companies interact to facilitate the adoption of AI by the latter), were associated with the economic field.

As illustrated in this Table, the ten most central actors are associated with at least two fields. Only Chris Arsenault, president of Inovia Capital, member of COGIA and partner at CDL, and Patrick Pichette, partner at Inovia Capital, member of the board of IVADO Labs and president of the board of Twitter, are not linked to the academic field. And only two of these ten actors are not directly associated with the political field, namely Hélène Desmarais, who participates in the integration of the economic and academic fields through her multiple functions in industry and her positions as Chairwoman of the Boards of HEC, IVADO Labs, CDL and Scale AI (co-chairmanship in this case) ${ }^{47}$. As for Andrea Lodi, he is Professor at École Polytechnique, member of the Board of Directors (BOD) and co-founder of IVADO Labs, member of the BOD of Scale AI and Chief Scientist of the CDL. The relationships

\footnotetext{
${ }^{47}$ We do not take into account here the fact that these people may have direct access to the political field through channels other than those analyzed in this paper.
} 
between the political field, the economic, and the academic fields are facilitated by the fact that the members of COGIA, who advise the Quebec government, are the same people who manage the AI research infrastructure (in addition to running several technology-based companies). The strong interactions between these three fields facilitate the formation of common goals ${ }^{48}$, such as the promotion of AI - more specifically of a sub-domain of AI, named "deep learning" - and the increase of public investments, all of which converge with their positions and interests.

Therefore, COGIA members, because of their positions outside the political field, have strong interests in seeing the Quebec government invest in AI, which explains why this committee seems to behave more like an interest group than an impartial panel of experts ${ }^{49}$. An analysis of the functions of COGIA members and observers (Table 5) shows that Mila is the most represented within this advisory council with six members, followed by CDL with five members, IVADO and IVADO Labs with four members, Scale AI and Inovia Capital with three members each. As for universities, UdeM, Polytechnique, HEC and McGill are all represented by technology transfer administrators. These universities are also the institutions that benefit the most from the new AI infrastructure in Quebec, as if nothing existed in other Quebec higher education institutions.

Given the affiliations of COGIA members, the three imperatives "at the heart of the strategy" of the Council are self-evident. They are indeed perfectly in line with the interests of its members:

1. We must guarantee the rise of MILA, the epicenter of machine learning, whose mission in terms of university research, training, technology transfer and social dialogue will support the AI development strategy in Quebec in a transversal way.

2. The whole of Quebec must be supported to fully contribute to this revolution in the historical sectors that have made its strength and in the capacity of the

\footnotetext{
${ }^{48}$ Luc Boltanski, loc.cit.

${ }^{49}$ Regarding interest or pressure groups, see Jérôme Boivin \& Stéphane Savard, « Pour une histoire des groupes de pression au Québec : quelques éléments conceptuels et interprétatifs », in Stéphane Savard \& Jérôme Boivin (Ed.), De la représentation à la manifestation : groupes de pression et enjeux politiques au Québec, XIX ${ }^{e}$ et $X X_{e}$ siècles, Québec, Septentrion, 2014, p. 16-40; James Yoho, "The Evolution of a Better Definition of "interest Group" and its synonyms", The Social Science Journal, vol. 35, no. 2, p. 231-243.
} 
Quebec education system as a whole to produce more AI and digital science specialists.

3. We must continue to support IVADO and SCALE AI, building on the growth they have experienced to date ${ }^{50}$.

In other words, it is recommended that Quebec increase its investments in universities with existing AI programs and increase its financial support to Mila, IVADO and Scale AI, which directly benefits all Council members except the two Deputy ministers.

In addition to these imperatives, COGIA also recommends "supporting Quebec companies that develop AI solutions, particularly startups, so that they can develop, grow and remain in Quebec"51, which is the market targeted by the latest funds created by Inovia Capital, a venture capital firm with three representatives, including its president Chris Arsenault, participating in COGIA's activities. In February 2019, taking advantage of the frenzy for AI, Inovia Capital launched two funds totaling US\$600 million with the support of Investissement Québec and the Caisse de dépôt et placement du Québec (CDPQ) to finance companies in the information technology and telecommunications sector ${ }^{52}$.

\footnotetext{
${ }^{50}$ Comité d'orientation de la grappe en intelligence artificielle, Stratégie pour l'essor de l'écosystème québécois en intelligence artificielle, Économie, science et innovation Québec, May 2018, p. 15; our translation.

51 Ibid., p. 45; our translation.

52 Chris Arsenault, «Comment nous avons mis sur pied une firme de capital-risque à part entière », Inovia blogue, February 19, 2019. https://blog-fr.inovia.vc/comment-nous-avons-mis-sur-pied-une-firme-de-capitalrisque-\%C3\%A0-part-enti\%C3\%A8re-d9a9508b3cc5; Gérard Bérubé, «Inovia amasse 600 millions », Le Devoir, February 20, 2019. https://www.ledevoir.com/economie/548219/capital-de-risque-inovia-amasse600-millions
} 
Table 5. Functions of COGIA members in the economic, political and academic fields (as of June 10, 2020)

\begin{tabular}{|c|c|c|c|}
\hline Names & Economic field & Political field & Academic field \\
\hline Chris Arsenault & $\begin{array}{l}\text { Co-founder and President - } \\
\text { Inovia Capital, Partner - CDL }\end{array}$ & Member - COGIA & \\
\hline Yoshua Bengio & $\begin{array}{l}\text { Member of BOD \& co- } \\
\text { founder - Element AI, } \\
\text { Member of BOD - Scale AI, } \\
\text { Chief Scientist - CDL, } \\
\text { Consultant - Microsoft, etc. }\end{array}$ & $\begin{array}{l}\text { Observator - COGIA, Co- } \\
\text { chair - CCMIA }\end{array}$ & $\begin{array}{l}\text { Scientific director - Mila, } \\
\text { Scientific director - IVADO }\end{array}$ \\
\hline François Bertrand & & Member - COGIA & $\begin{array}{l}\text { Member of BOD - Mila, } \\
\text { Senior Vice-President } \\
\text { General Directorate \& } \\
\text { Vice-President } \\
\text { Academic and Research } \\
\text { Directorate - Polytechnique }\end{array}$ \\
\hline Pierre Boivin & $\begin{array}{l}\text { CEO - Claridge Inc, Member } \\
\text { of BOD - Canadian Tire, } \\
\text { idem - Export Development } \\
\text { Canada, idem - Banque } \\
\text { nationale, etc. }\end{array}$ & $\begin{array}{l}\text { Co-chair - COGIA Member - } \\
\text { CCMIA }\end{array}$ & Chairman of the BOD - Mila \\
\hline Thomas Birch & $\begin{array}{l}\text { Global Managing Director, } \\
\text { venture capital and } \\
\text { Technology - CDPQ }\end{array}$ & Member - COGIA & \\
\hline Marie- Josée Blais & & $\begin{array}{l}\text { Observator - COGIA, } \\
\text { Assistant Deputy Minister - } \\
\text { MÉSI }\end{array}$ & \\
\hline Mario Bouchard & & $\begin{array}{l}\text { Observator - COGIA, } \\
\text { Assistant Deputy Minister - } \\
\text { MÉSI }\end{array}$ & \\
\hline Charles Boulanger & CEO - Leddar Tech & Member - COGIA & \\
\hline Guy Breton & & Co-chair - COGIA & $\begin{array}{l}\text { Rector - UdeM, Member of } \\
\text { BOD - HEC, Member of } \\
\text { BOD - Polytechnique }\end{array}$ \\
\hline Magaly Charbonneau & $\begin{array}{l}\text { Vice President Investments - } \\
\text { Inovia Capital, Partner - CDL }\end{array}$ & & Member of BOD - Mila \\
\hline Martha Crago & Member of BOD - Scale AI & Member - COGIA & $\begin{array}{l}\text { Member of BOD - Mila, } \\
\text { Vice-Principal (Research and } \\
\text { Innovation) - McGill }\end{array}$ \\
\hline Robert Gagné & Chief economist - CDL & Member - COGIA & $\begin{array}{l}\text { Member of BOD - IVADO } \\
\text { Labs, Associate Director, } \\
\text { Research and Knowledge } \\
\text { Transfer - HEC }\end{array}$ \\
\hline Marie-Josée Hébert & & Member-COGIA & $\begin{array}{l}\text { Secretary - Mila, Vice- } \\
\text { Principal (Research and } \\
\text { Innovation) - UdeM }\end{array}$ \\
\hline Patrick Pichette & $\begin{array}{l}\text { General partner - Inovia } \\
\text { Capital, Fellow - CDL }\end{array}$ & Member - COGIA & $\begin{array}{l}\text { Member of BOD - IVADO } \\
\text { Labs }\end{array}$ \\
\hline Doina Precup & $\begin{array}{l}\text { President - Google } \\
\text { DeepMind Mtl, President - } \\
\text { Pan-Canadian AI Strategy } \\
\text { (CIFAR) }\end{array}$ & Observator - COGIA & Professor - McGill \\
\hline Gilles Savard & Member of BOD - Scale AI & Observator - COGIA & $\begin{array}{l}\text { General director- IVADO, } \\
\text { Member of BOD - IVADO } \\
\text { Labs }\end{array}$ \\
\hline Valery Zamuner & $\begin{array}{l}\text { Vice-President, Mergers, } \\
\text { Acquisitions \& Strategic } \\
\text { Initiatives - Stingray }\end{array}$ & Member - COGIA & \\
\hline
\end{tabular}




\subsection{Betting everything on one horse}

As shown in Figure 2, the most central and therefore influential actor of AI in Quebec is unquestionably Yoshua Bengio, professor in the Department of Computer Science and Operations Research at the University of Montreal and one of the most enthusiastic promoters of AI in the public sphere. Widely recognized scientifically, along with Geoffrey Hinton (in Toronto) and Yann LeCun (at Facebook), as one of the pioneers of so-called "deep learning", Yoshua Bengio has been active in AI since the 1980s. Having completed his PhD at McGill University in 1991, he continued his research as a postdoctoral fellow at MIT in 1991-1992. While he has published papers on "synaptic" learning algorithms since the early $1990 \mathrm{~s}^{53}$, like many other "connectionist" ${ }^{54}$ researchers, it wasn't until the mid-2000s ${ }^{55}$ that his techniques, and those of his colleagues Geoffrey Hinton and Yann LeCun ${ }^{56}$, became truly paradigmatic, in the sense that many researchers considered them - and still do - convincing enough to make them the starting point for further work in $\mathrm{AI}^{57}$. Since then, his work has become a must-read for researchers and has been widely cited in scholarly publications and conference proceedings.

This pioneering position in the field of machine learning has placed him at the heart of the development of AI in Quebec. In fact, he is considered by many as one of the most important "attraction" factors for AI in Montreal ${ }^{58}$. It would be more accurate, however, to describe him as a credibility factor for the artificial intelligence stakeholders. Indeed, the latter make

\footnotetext{
${ }^{53}$ Yoshua Bengio, Samy Bengio \& Jocelyn Cloutier, "Learning a synaptic learning rule", International Joint Conference on Neural Networks (IJCNN), Seattle, 1991.

${ }^{54}$ For a brief history of the connexionnist paradigm, see Dominique Cardon, Jean-Philippe Cointet \& Antoine Mazières, «La revanche des neurones : L'invention des machines inductives et la controverse de l'intelligence artificielle », Réseaux, vol. 5, no. 211, 2018, p. 173-220.

${ }^{55}$ Especially following the publication of an article on multilayer "neural" network with his student Hugo Larochelle. See Yoshua Bengio, Pascal Lamblin, Dan Popovici \& Hugo Larochelle, "Greedy Layer-Wise Training of Deep Networks", dans Bernhard Schölkopf, John Platt, and Thomas Hoffman (dir.), NIPS. MIT Press, 2006, p. 153-160. http://www.iro.umontreal.ca/ lisa/pointeurs/BengioNips2006All.pdf

${ }^{56}$ It is however in 2012 that deep learning theories surpassed the more classical theories in popularity, thanks to a study by Hinton and two colleagues on image classification. See A. Krizhevsky, I. Sutskever \& G.E. Hinton, «Imagenet classification with deep convolutional neural networks », NIPS, 2012, p. 1097-1105.

${ }^{57}$ To use the formulation of Thomas Kuhn, The Structure of Scientific Revolutions, Chicago, University of Chicago Press, 1996.

${ }^{58}$ David Doloreux \& Geneviève Savoie-Dansereau, «L'émergence de la grappe industrielle de l'intelligence artificielle (IA) à Montréal », Le Géographe canadien, 2019, p. 1-13.
} 
ample use of his symbolic capital ${ }^{59}$ to justify their practices and provide credibility to their decisions, while Yoshua Bengio himself takes advantage of such attention to guide the development of AI in the direction of "deep learning" - only one among many branches of AI - and attract funding to achieve his dream of making Montreal a second "Silicon Valley"

Since the mid-2010, AI promoters have turned Yoshua Bengio's scientific achievements into an argument of authority that alone justifies all requests for funds. They established a direct link between his scientific accomplishments and the hypothetical success of the industrial projects announced for the coming years in the Quebec metropolis. In a brochure published to attract capital from foreign investors, the state-owned corporation Investissement Québec, for example, emphasizes the presence of Bengio to promote the idea that Montreal is a safe bet: "Montreal boasts an exceptionally high concentration of expertise in the area of AI, thanks in part to the efforts of University of Montreal professor Yoshua Bengio, one of the founding fathers of the deep learning movement and head of the Montreal Institute for Learning Algorithms (MILA)" ${ }^{\prime 61}$.

The same rhetoric was used by Microsoft in 2017 when it acquired Maluuba, a company specializing in language recognition. At that time, Harry Shum, Vice President of the Microsoft AI and Research Group, quickly announced that "Yoshua Bengio, one of the world's foremost experts in deep learning, head of the Montreal Institute for Learning Algorithms and an advisor to Maluuba, will also be advising Microsoft and interacting directly with me" ${ }^{\prime 62}$. The COGIA, for its part, tried to convince the government to invest in artificial intelligence by emphasizing the presence of the professor: "several world-renowned

\footnotetext{
${ }^{59}$ Pierre Bourdieu, «Les trois états du capital culturel », Actes de la recherche en sciences sociales, vol. 30, 1979, p. 3-6.

${ }^{60}$ Karen Seidman, "Montreal universities land historic \$213M investment for computer and brain research", The Montreal Gazette, June 15, 2017.

61 Investissement Québec, «Montreal's Artificial Intelligence Hub», Information and Communication technologies, June 2019; our translation, bold in the original.

62 Harry Shum, «Microsoft acquires deep learning startup Maluuba; AI pioneer Yoshua Bengio to have advisory role ", Microsoft Blog, January 13, 2017. https://blogs.microsoft.com/blog/2017/01/13/microsoftacquires-deep-learning-startup-maluuba-ai-pioneer-yoshua-bengio-advisory-role/
} 
scientists, including one of the three pioneers of deep learning, Professor Yoshua Bengio, are based in Quebec" ${ }^{\prime 3}$.

Yoshua Bengio is thus positioned as the master card and one of the main driving forces behind the development of AI in Quebec. As shown in Figure 2, he is directly or indirectly linked to all AI stakeholders, since he has been involved in most of the publicly funded AI initiatives since the mid-2010 and participates in the activities of the Quebec and Canadian advisory councils.

At the government level, he has used his scientific reputation to position himself as one of the most sought-after advisors in both Quebec and Ottawa. He is an observer of the COGIA, established by the Quebec government in 2017, and co-president of the Conseil consultatif en matière d'intelligence artificielle (CCMIA), created by Ottawa in 2019 to participate in the "development of government policies in areas related to AI"64. His duties, however, are not limited to advising; he is also one of the beneficiaries of government policies and related funding. He is the Scientific Director of Mila, Scientific Director of IVADO, Chief Scientist of CDL and a member of the Board of Directors of Scale AI. These organizations alone, led in part by Yoshua Bengio, will control more than $\$ 550$ million in public funding in the coming years, which constitutes more than $50 \%$ of the public funds invested in the AI research infrastructure in Quebec and makes the professor one of the most influential in guiding the use of these public moneys.

In addition to these public initiatives, his scientific notoriety, highlighted when he was awarded (along with his colleagues LeCun and Hinton) the prestigious Alan Turing Prize in $2018^{65}$ - which the media enhanced to a "Nobel Prize in Computer Science" to make it even more prestigious in the public eyes ${ }^{66}$ - has given him the opportunity to offer his consulting

\footnotetext{
${ }^{63}$ Comité d'orientation de la grappe en intelligence artificielle, Stratégie pour l'essor... op.cit., p. 25; our translation.

${ }^{64}$ Government of Canada, Mandat du Conseil consultatif en matière d'intelligence artificielle du Gouvernement du Canada, May 14, 2019; our translation.

65 "Fathers of the Deep Learning Revolution Receive ACM A.M. Turing Award: Bengio, Hinton, and LeCun Ushered in Major Breakthroughs in Artificial Intelligence", ACM Awards, June 15, 2019.

${ }^{66}$ A similar case is the pseudo "Nobel Prize in Economics"; see Yves Gingras, « Beautiful mind, non existent prize », in Edward Fullbrook (Ed.), Real World Economics. A Post-autistic Economics reader, London, Anthem Press, 2007, pp. 71-77.
} 
services to the technology giants that have settled in Montreal in recent years, such as IBM and Microsoft ${ }^{67}$. Both a researcher and an entrepreneur, he also contributed to the creation of Imagia, a joint stock company working in the medical field founded by Alexandre Le Bouthillier, a member of Mila's board of directors, and Nicolas Chapados, co-founder of Element AI and a former student of the professor. On its website, Imagia is careful to recall that the recruitment of its staff has been done in close collaboration with Yoshua Bengio, "a world-renowned expert considered as one of the fathers of deep learning" ${ }^{68}$. As an entrepreneur, the professor also founded, with others, the company Element AI in October 2016. He is one of the major shareholders of Apsat Technologies Inc. which was, as of October 2020, the third largest shareholder of Element AI, and he was still (at that same date) on the board of directors of Element $\mathrm{AI}^{69}$. Building on the scientific reputation of its founder, Element AI secured a $\$ 5$ million loan from the federal government in $2018^{70}$ and more than $\$ 130$ million in private investments from companies such as Microsoft Corp, Intel Corp, Nvidia Corp, and Tencent Holdings Ltd in $2017^{71}$.

Yoshua Bengio's partners at Element AI are well aware of the importance of governments in creating an AI-friendly environment. The company is listed in the Quebec and Canadian lobbyists registers and has been involved since September 2017 in a vast campaign to lobby the Quebec government into promoting an "ecosystem favorable to the development of artificial intelligence" 72 . Since the beginning of 2019, its lobbyists have also been asking that

\footnotetext{
${ }^{67}$ Allison Linn, "Microsoft announces significant expansion of Montreal research lab, new director", The $A i$ Blog, Microsoft, January 23, 2018. https://blogs.microsoft.com/ai/montreal-ai-research-expansion/; "IBM to open an Ai lab in Montreal to better collaborate with Mila", UdeM Nouvelles, April 20, 2017. https://nouvelles.umontreal.ca/en/article/2017/04/20/ibm-to-open-an-ai-lab-in-montreal-to-better-collaboratewith-mila/

${ }^{68}$ Imagia, « Notre histoire », https://imagia.com/fr/a-propos/ (Consulted 2020/06/22); our translation.

${ }^{69}$ E. Turkina, "The importance of networking to entrepreneurship: Montreal's artificial intelligence cluster and its born-global firm Element AI", Journal of Small Business \& Entrepreneurship, vol. 30 no.1, 2018, p.1-8.

70 Jessica Galang, "Element AI Receives \$5 million loan from Canadian Government", Betakit, Canadian startup news and tech innovation, December 5, 2018. https://betakit.com/element-ai-receives-5-million-loanfrom-canadian-government/

${ }^{71}$ Sean Silcoff, "Canada's AI dream: Montreal-based innovator Element AI has impressive backers and a hefty bankroll, but can it deliver what it promises? Sean Silcoff investigates", The Globe and Mail, July 20, 2019. See also Peter H. Diamandis \& Steven Kotler, Bold: How to Go Big, Create Wealth and Impact the World, New York, Simon \& Schuster, 2015.

72 Element AI's lobbyists at this time were Caroline Bourbonnière, Nicolas Chapados, Jean-Sébastien Cournoyer, Jean-François Gagné et Anne Martel. See Registre des lobbyistes du Québec, «Sommaire de
} 
Quebec "facilitate the adoption of artificial intelligence solutions within the public service" and are pressuring the government "to obtain funding for an undetermined amount, in the form of equity participation, from the Fonds de développement économique du Québec ${ }^{73}$.

Such lobbying activities are infrequent in start-ups, but Element AI is no ordinary start-up. It is inspired by the principle of "supercredibility" developed by Silicon Valley entrepreneur Peter Diamandis. Characteristic of promoters' buzzwords, the idea is simple: "start at the top and build your way up" ${ }^{74}$. But such a strategy is expensive, and this is even more true in the case of Element AI. Since 2016, the company, which has grown dramatically before it even had a single product to offer, and which now has less than 500 employees following the layoff of at least $15 \%$ of its workforce ${ }^{75}$, is struggling to deliver on its promises; its major projects are facing important setbacks. According to journalist Sean Silcoff, "Element AI as of early this year (2019) did not yet qualify among the top level of AI suppliers entitled to bid for government business because it hadn't delivered at least five successful AI projects"76.

These difficulties, however, in no way call into question the ambitions of AI promoters. Yoshua Bengio said it better than anyone: "there's no way we're going to succeed if we don't push on the gas as much as is reasonable",77. And the States, already strongly committed to AI, share this confidence. On September 13, 2019, at the conclusion of Element AI's second fundraising campaign, which raised $\$ 200$ million, the Quebec government announced that the Caisse de dépôt et placement (CDPQ), which manages the retirement fund of Quebecers, will invest $\$ 99$ million in the company and that the government will also contribute $\$ 33$

l'inscription no E17-LE03452 de l'entreprise Element AI Inc. Par Jean-François Gagné, plus haut dirigeant », September 27, 2017; our translation.

73 The team of lobbyists for this mandate has more than doubled compared to the mandate beginning September 27, 2017. It consisted of Frédérique Bouchard, Caroline Bourbonnière, Nicolas Chapados, Jean-Sébastien Cournoyer, Philip Dawson, Simon-Pierre Diamond, Philip Donelson, Julien Dubois, Jean-François Gagné, Sarah Larose, Mathieu Marcotte, Anne Martel, Frédéric Michaud, Marc-Étienne Ouimette et Xavier Trépanier Taupier. See Registre des lobbyistes du Québec, «Sommaire de l'inscription no E19-LE00815 de l'entreprise Element AI Inc. Par Jean-François Gagné, plus haut dirigeant », April 24, 2019; our translation.

${ }^{74}$ Peter Diamandis quoted in Sean Silcoff, "Canada's AI dream...", loc.cit.

${ }^{75}$ Francis Halin, « Près de 50 mises à pied chez Element AI », Journal de Montréal, May 16, 2020; Sean Silcoff, «Element AI cuts staff, adds senior executives as it attempts to live up to early hype: Element heralded itself as the champion of Montreal's flourishing AI sector from its 2016 founding, promising to bring AI to a range of industries », The Globe and Mail, May 5, 2020.

76 Sean Silcoff, "Canada's AI dream...", loc.cit.

77 Yoshua Bengio quoted in Ibid. 
million to its funding ${ }^{78}$, for a total of approximately $\$ 132$ million of public money for a company that did not yet have any products, but which promised many ${ }^{79}$. The proportions of public and private money in this second fundraising campaign are meaningful. The CPDQ and the Quebec government alone contributed 66\% of the funds invested, while McKinsey \& Company, the largest investor after the Quebec public sector, contributed only $9 \%$ of the funds raised (approximately $\$ 19$ million) ${ }^{80}$. If we compare these proportions with Element AI's first fundraising campaign, which was entirely financed by corporations in 2017, it seems that the private sector's confidence in the Montreal company was eroding. The public sector, which has invested heavily in the promotion of AI in Montreal, was thus forced to take the lead, since the failure of a central actor of AI in Montreal would be excessively damaging to the image of this technology in Quebec and could undermine the credibility of the public policies implemented in recent years.

Barely a month after the announcement of this funding, the company organized a cocktail party worthy of "Silicon Valley" startups at the Assemblée nationale in Quebec City. Using the rhetoric of public service, the event was entitled Cocktail Element AI: Artificial intelligence at the service of the Quebecers. As reported in the promotional brochure of the Observatoire international sur les impacts sociétaux de l'AI et du numérique (International Observatory on the Societal Impacts of AI), Element AI invited “public decision-makers" at the Assemblée nationale to "talk to them about the most recent developments in AI in a convivial and festive context". Ministers such as Pierre Fitzgibbon and Eric Caire, who were both present at the event, enjoyed "hors d'oeuvres", "refreshments" and an "ice cream bar" while they chatted with the main promoters of AI in Quebec. Even more surreal, a ping-pong tournament was organized to allow the elected representatives to compete against various stakeholders of AI.

\footnotetext{
${ }^{78}$ We converted the funding into Canadian dollars using the current exchange rate. The amounts announced in U.S. dollars are as follows: CPDQ (US\$75 million); Government of Quebec (US\$25 million).

79 Sean Silcoff, "Element AI closes financing, securing \$200-million backed by the Caisse, Quebec and McKinsey", Globe and Mail, September 16, 2019.

${ }^{80} \mathrm{Ibid}$.
} 
Despite all these efforts, on November 30, 2020, we learned that Element AI had been bought by American interests (ServiceNow) for only 230 million $^{81}$, an amount that confirm the extent of the difficulties encountered by the company previously presented as one of the instigators of the AI "revolution" in Quebec and whose value (essentially speculative) was still estimated to be over 600 million dollars in September $2019^{82}$.

If, legally speaking, the multipositioning of certain actors who are at the same time policy advisors, entrepreneurs and researchers do not place them in a situation of conflict of interests, according to the Loi sur les conflits d'intérêts, which applies only to public officials $^{83}$, the fact remains that this ubiquity clearly raises the question of the appearance of conflicts of interests or at least what ethicists now call - in a kind of euphemism - "ties of interest" $"$. Indeed, jurists generally conceive that a "person is in a conflict of interest if (a) he or she is in a relationship of trust with another person in whose service he or she exercises judgment and (b) he or she has an interest tending to interfere with the exercise of that

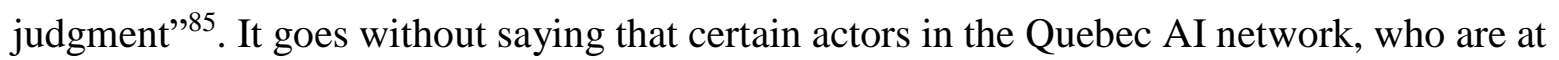
once policy advisors, entrepreneurs, and academics, seem to benefit from government policies.

\footnotetext{
${ }^{81}$ Sean Silcoff, "Element AI sold for \$230-million as founders saw value mostly wiped out, document reveals", The Globe and Mail, December 18, 2020.

${ }^{82}$ Sean Silcoff, «Once touted as a technology world-beater, Montreal's Element AI sells out to Silicon Valley giant », The Globe and Mail, November 30, 2020; Ingrid Lunden, « ServiceNow is acquiring Element AI, the Canadian startup building AI services for enterprises », Tech Crunch, November 30, 2020.

${ }^{83}$ Loi sur les conflits d'intérêts, L.C. 2006, ch. 9, art. 2.

${ }^{84}$ See Jean-Christophe Bélisle-Pipon, Louise Ringuette, Anne-Isabelle Cloutier, Victoria Doudenkova \& Bryn Williams-Jones, «Conflicts of interest and the (in)dependence of experts advising government on immunization policies ", Vaccine 36 (2018) 7439-7444; Bryn Williams-Jones, Jean-Christophe Bélisle-Pipon, Louise Ringuette, Anne-Isabelle Cloutier \& Victoria Doudenkova, "Experts sous influence? Quand la non-divulgation des conflits d'intérêts met à risque la confiance du public" in C. Hervé, M. Stanton Jean \& M-F. Mamzer (eds.), Autour de l'intégrité scientifique, la loyauté, et la probité : aspects clinique, éthiques et juridiques, Paris, Dalloz, 2016, p. 27-44.

${ }^{85}$ Michael Davis quoted in N.E. Bowie, University-Business Partnerships. An Assessment, Lanham, Rowman \& Littlefield, 1994, p. 67. It should be noted, however, that the notion of conflict of interest is not frozen in time. It has evolved according to socio-historical contexts. On this subject, Yves Gingras \& P.-M. Gosselin, "The Emergence and Evolution of the Expression "Conflict of Interests" in Science: A Historical Overview, 1880-2006 », Science and Engineering Ethics, volume 14, 2008, p. 337-343; Yves Gingras, Pierrick Malissard \& Jean-François Auger, «Les conditions d'émergence des "conflits d'intérêts" dans le champ universitaire ", Éthique publique, vol. 2, no. 2, 2000, p. 126-137.
} 


\subsection{An influential and interested advisor}

Another stakeholder, coming from the corporate world, plays a central role within the Quebec AI network: Pierre Boivin He is CEO of Claridge Inc., a private investment company that represents the interests of the Bronfman family. Investing highly in technology, Claridge quickly turned to AI and is mobilizing the rhetoric of "technological gap" to call for more public investment ${ }^{86}$. According to Claridge, it is critical that Canada invest heavily in this technology because "despite our early scientific lead, we're losing ground to the AI superpowers". In a press release issued in March 2017, the investment firm called for the training of AI students, the establishment of "conditions for entrepreneurs to succeed" through access to data and venture capital in particular - and the creation of a technology transfer infrastructure that would provide an opportunity "for Canadian companies to work closely with academics" ${ }^{\$ 7}$, all actions that Quebec and Ottawa are currently following.

Claridge's rationale for artificial intelligence "made in Canada" is quite simple. By advocating that the country become "nothing less than [...] a world leader in AI science and its applications in the marketplace" ${ }^{\prime 88}$, the company probably hopes to take advantage of new business and investment opportunities ${ }^{89}$. With its partner Canderel, a firm active in real estate, they, for example, own a building in Mile-Ex in order to benefit from the expansion of AI in that area. When Microsoft moved its Montreal AI laboratory in 2018 to 6795 Marconi street, just across the O-Mile-Ex complex, the multinational chose to establish itself in one of the joint properties of Claridge and Canderel ${ }^{90}$.

\footnotetext{
${ }^{86}$ Julie Bouchard, Comment le retard vient aux Français: Analyse d'un discours sur la recherche, l'innovation et la compétitivité 1940-1970, Paris, Presses universitaires du Septentrion, 2008.

${ }^{87}$ Claridge Inc., "It's time for Canada to invest in developing artificial intelligence”, March 29, 2017. ${ }^{88}$ Ibid.

${ }^{89}$ Pierre Boivin is mainly interested in technology transfer. He constantly stresses the importance of transferring university discoveries to companies. For example, in the magazine "L'Ordre des ingénieurs du Québec", he stated that "we will need a lot of engineers in this sector who will be able to build bridges between fundamental research and business solutions, in order to prepare ourselves for the advent of artificial intelligence in our lives" [translation]. See "Intelligence artificielle: comment l'IA s'apprête-t-elle à changer nos vies et le travail d'ingénieur », PLAN, Le revue de l'ordre des ingénieurs du Québec, March-April, 2018, p. 38.

90 Microsoft, «Microsoft Research Montreal Relocating to Mile-Ex Neighborhood in Montreal, Growing its Research Talent and Deepening Investment in Canada's Thriving AI Hub », Microsoft News Center Canada, September 18, 2018.
} 
In addition, Claridge's CEO is one of the leading AI advisors in Quebec and Ottawa. It is through his involvement in the Conseil consultatif sur l'économie et l'innovation (CCEI), formed by the Quebec government in 2016 to "formulate proposals to strengthen innovation and research"91, that Pierre Boivin first advised the government on the development of artificial intelligence. Composed of more than 30 businessmen and women, including the CEO of Google Canada and the President of Optel Group, the CCEI promoted AI to the Quebec government. According to its members, "for the first time in our recent history, Quebec is in a position to be there at the birth of an extraordinary source of knowledge and economic development". Following this logic, it would be necessary to "create in Quebec the most important artificial intelligence ecosystem in North America and develop a work force in this field in order to anchor this niche in Quebec and become one of the main designers, users and exporters of artificial intelligence solutions" ${ }^{92}$.

Listened to by the government, which confirmed drawing inspiration from its recommendations in its 2018 budget, the CCEI enabled Pierre Boivin to become an influential figure of AI and to be appointed co-president, along with Guy Breton, then UdeM rector, of the COGIA formed in May 2017. As mentioned above, this committee wrote the Stratégie pour l'essor de l'écosystème québécois en intelligence artificielle published in May 2018. Made public in June of the same year by Minister Dominique Anglade, she unsurprisingly adopted the rhetoric of "technological revolution", omnipresent in the report, to endorse its recommendations:

Thanks to the committee's recommendations, we will be able to create a dynamic business environment favoring, among other things, the integration of artificial intelligence by Quebec companies and organizations. Artificial intelligence represents a unique opportunity to capitalize on the knowledge of our researchers and mobilize the talent of our workers, entrepreneurs, and students so that Québec can become the leader of a revolution that, if properly carried out, will lead to considerable progress in many fields of activity. I would therefore like to thank the members of the Comité d'orientation de la grappe en intelligence artificielle for their commitment and their undeniable contribution to the

\footnotetext{
${ }^{91}$ Conseil consultatif sur l'économie et l'innovation, « Agir ensemble : pour un Québec, innovant, inclusif et prospère », Quebec, September 2017, p. 88; our translation.

92 Ibid., p. 7.
} 
development of a dynamic ecosystem that will ensure the success of this technological revolution in Québec ${ }^{93}$.

Among all COGIA's recommendations, one stands out. The committee led by Pierre Boivin and Guy Breton concluded that the Quebec government should invest:

80 million to support the development of MILA, \$65 million first and the granting of the balance of $\$ 15$ million conditional on meeting milestones (to be established with MESI). The growth of this institute is the spearhead of the strategy for the development of AI in Quebec and serves several strategic directions of this report: establishment of a pole of excellence in research, development of talent, spin-offs of AI start-ups, appropriation of AI skills by the Quebec technology transfer network, significant contribution to the reflection on responsible AI and better access for AI researchers to the computing power and expertise they need ${ }^{94}$.

This recommendation is interesting because it magnifies the general dynamics of AI in Quebec: the link between the interests of policy advisors and their recommendations. It encapsulates COGIA's particular attention to Mila, considered to be the centerpiece of AI development in Quebec. The two presidents of the committee have a clear interest in having the government invest its millions in Mila. The University of Montreal and its affiliated schools are the founders of Mila (with McGill), and the new funds constitutes a unique research opportunity for the researchers working at the university of which Mr. Breton was then the rector. It is only logical that Mr. Breton would promote a center attached to his institution, overlooking nearly all other Quebec universities in the process. As for Pierre Boivin, he was appointed Chairman of the Board of Directors of Mila in July 2017, one year before the publication of the COGIA report, which might be perceived by some as an apparent conflict of interests, although, let's repeat, this does not of course violate any law. We simply find here the same organizational logic of concentration of all AI-related decisions in Quebec in the hands of a dozen multipositioned actors.

\footnotetext{
${ }^{93}$ Dominique Anglade, quoted in Government of Quebec, « Rapport du Comité d'orientation de la grappe en intelligence artificielle : Cinq orientations stratégiques pour renforcer l'écosystème québécois en intelligence artificielle », Press release, June 21, 2018; our translation. https://www.economie.gouv.qc.ca/ministere/sallede-presse/communiques-de-presse/communique-depresse/?no_cache $=1 \&$ tx_ttnews $\% 5 \mathrm{Btt} \_n e w s \% 5 \mathrm{D}=22551 \& \mathrm{cHash}=\mathrm{d} 03 \mathrm{cb} 0 \mathrm{c} 33719 \mathrm{e} 26 \mathrm{~b} 7 \mathrm{e} 1493 \mathrm{a} 56 \mathrm{aebcc0c}$;

${ }^{94}$ Comité d'orientation de la grappe en intelligence artificielle, Stratégie pour l'essor de l'écosystème québécois..., op.cit., p. 80; our translation.
} 


\section{Conclusion: the limits of resource concentration}

Since the 1980s, national R\&D priorities have been strongly influenced by successive trends: after the biotechnologies of the 1980s and the nanotechnologies of the 2000s, we are now witnessing the wave - or even the tsunami - of artificial intelligence. It's as if Quebec (or even Canada) really believed it could "compete" with the large American or global corporations that invest billions in these projects, not to mention those funded by the U.S. government agency DARPA, which recently announced that it would invest $\$ 2$ billion in a new program, "AI Next". Concentrating most of the available funds in a very limited number of areas made visible through lobbying and public announcements of upcoming "major breakthroughs" may not be the best use of public funds for a province that produces only about $1 \%$ of the world's scientific publications and should therefore ensure that it has the capacity to use and benefit from the $99 \%$ produced by the rest of the world.

Therefore, let's take a step back and reflect more generally on the limitations of policies that tend to concentrate most resources on a particular area, which is always promoted by interested actors ${ }^{95}$. Since the late 1980s, we have seen a new rhetoric of "excellence" accompanying the idea of concentrating resources on a small number of priorities in order to maximize, as we say in finance, the "return on investment". This conception of science and technology policies probably helps explain why Quebec's R\&D priorities have successively focused on biotechnologies in the 1980s, nanotechnologies at the turn of the century and artificial intelligence in the 2010s. In all these cases, government investments were based on the optimistic and often highly exaggerated promises of researchers and lobbyists assuring us that Quebec could become a "world leader" in these fields.

What we are currently witnessing in $\mathrm{AI}$ is not without analogy with the period of the early 2000s, which saw a strong craze by governments for nanotechnologies. The hype was similar and led to the creation in 2001 of NanoQuébec, which changed its name in 2015 to become "Prima Québec", less spectacular and less explicitly associated with an image of

\footnotetext{
95 Part of this conclusion reproduce an analysis developed in Yves Gingras, «The Quebec Research and
} Innovation System », in David Castle et Peter Phillips (Eds.), STI Policy in Canada, UofT Press, forthcoming. 
"nanotechnology" that was finally difficult to market ${ }^{96}$. Quebec was no exception, and in the United States as well, the National Cancer Institute (NCI) decided to close its Centers of Cancer Nanotechnology Excellence (CCNEs) as the promises of the "nanotechnology revolution" began to crumble. As we have seen throughout this study, the same story is repeating itself today without any critical distance from the promoters of the new "AI revolution". And it is not certain that the recent Element AI debacle opened the eyes of those who like to dream of world domination in at least one technological field.

In response to these promoters, who argue that humanity is about to enter a revolutionary period thanks to AI and that the government should invest hundreds of millions of public dollars to catch up on a so-called "technological gap", Quebec and Ottawa are concentrating their investments in science and technology in the field of AI, and even in a subfield of AI, namely that of so-called "deep" machine learning techniques. In such context, policy makers choose to invest to show that they are acting, knowing that even if the extraordinary promises do not materialize soon, citizens will likely have forgotten them in a couple of years. On the other hand, not moving in the direction suggested by lobbies and prominent public scientists would be denounced - and amplified by uncritical and easily dazzled media - as a lack of will and courage that could put "the future of the country at risks".

It can therefore be expected that, from time to time, organizations that already receive millions of dollars in public funds will simply claim that they need even more to maintain or regain their "leadership" in the "global competition". For instance, as early as January 2019, less than two years after the Quebec government announced a first wave of investment in AI, Mila CEO Valérie Pisano told Le Devoir that "what we've had in recent years has been basic, start-up investments. What was envisaged was a horizon of three to five years, which is fantastic. That allowed the Mila to flourish, [...] but it's not enough"97. This rhetoric contributes to the concentration of public investment in AI and makes us forget that the most

\footnotetext{
${ }^{96}$ Maxime Colleret \& Mahdi Khelfaoui, «D'une révolution avortée à une autre? Les politiques québécoises en nanotechnologies et en IA au prisme de l'économie de la promesse », Recherches sociographiques, 2021 (forthcoming).

${ }^{97}$ Karl Rettino-Parazelli, « Nouveaux bureaux, nouveaux besoins pour Mila », Le Devoir, January 29, 2019, https://www.ledevoir.com/economie/546567/nouveaux-bureaux-nouveaux-besoins
} 
important "competitors" invest hundreds of times the total amount of R\&D budget of Quebec in AI alone. Moreover, despite these investments by Quebec and Ottawa, Canada is not among the top countries in terms of publications and number of researchers in the field ${ }^{98}$.

This dynamic reflects what sociologists of technology call speculative bubbles ${ }^{99}$. According to Pierre-Benoît Joly:

the promoters of technoscientific promises are merchants of hope and do not fail to exaggerate the possibilities of technological solutions. Promises thus behave like speculative bubbles: expectations generate over-investment which inevitably leads to disappointment when the results are not up to expectations, which causes a drop in resources ${ }^{100}$.

Gartner's "technological hype" model also provides a useful, though simplified, representation of the life cycle of rhetoric accompanying various new technologies promoted as revolutionary ${ }^{101}$. The three phases are: excitement, hope and disillusion. The cases of biotechnology and nanotechnology have gone through all these phases and are now forgotten. On this basis, one can also expect that the still recent hype surrounding AI will soon be replaced by a more rational hope before AI simply become a technology with useful applications, although they will be far from the most optimistic and even fanciful predictions.

In fact, some researchers are currently calling for a more reasonable discussion of the real potential of artificial intelligence. In a paper written in 2018, the American researcher Gary Marcus reminded his colleagues of this: "one of the biggest risks in the current overhyping of $\mathrm{AI}$ is another $\mathrm{AI}$ winter... [...] Although there are vastly more practical applications of AI now than there were in the 1970s, hype is still a major concern"102. In a more recent article published in June 2020, The Economist newspaper mentions that, despite the undeniable

\footnotetext{
${ }^{98}$ Sara O,Meara, «Will China lead the world in AI by 2030? », Nature, 572, 2019, p. 427-428.

${ }^{99}$ Pierre-Benoît Joly, « On the Economics of Techno-scientific Promises », in M. Akrich, Y. Barthe, F. Muniesa \& P. Mustar (Ed.) Débordements. Mélanges offerts à Michel Callon, Paris, Presses des Mines, 2010, p. 203222.

100 Pierre-Benoît Joly, «Le régime des promesses technoscientifiques », in M. Audétat, Pourquoi tant de promesses, Paris, Hermann, 2015, p. 31-48; our translation.

${ }^{101}$ For a review of the limitations of this model see, among others, M. Borup, N. Brown, K. Konrad \& H. Van Lente, "The sociology of expectations in science and technology" Technological Forecasting and Social Change, vol. 18, no. 3-4, 2006, p. 285-298.

${ }^{102}$ Gary Marcus, «Deep Learning: A Critical Appraisal », ArXiv, 2018, p. 17-18.
} 
success of AI in certain areas, "the fact remains that many of the grandest claims made about AI have once again failed to become reality, and confidence is wavering as researchers start to wonder whether the technology has hit a wall'. Echoing Geoffrey Hinton's 2016 assertion that we should stop training radiologists because the profession will soon be completely replaced by computers ${ }^{103}$, The Economist set the record straight, noting with some irony that efforts "to incorporate AI into medical diagnosis are, similarly, taking longer than expected: despite Dr. Hinton's prediction, there remains a global shortage of human radiologists"104. In short, the famous British weekly newspaper perhaps suggested to computer scientists excited by a few technical achievements that they should continue to be computer scientists rather than gurus who confidently - and sometimes arrogantly - predict the future of societies ${ }^{105}$.

${ }^{103}$ Geoffrey Hinton, "Machine Learning and the Market for Intelligence", Creative Destruction Lab, 2016. https://www.youtube.com/watch?v=2HMPRXstSvQ

104 "Artificial intelligence and its limits: An understanding of AI's limitations is starting to sink in », The Economist, June 11, 2020.

${ }^{105}$ On these issues, see for example, Antonio A. Casilli, En attendant les robots, Paris, Seuil, 2019; Meredith Broussard, Artificial Unintelligence, Cambridge, Mass, MIT Press, 2018. 


\title{
Autres titres de cette collection
}

\author{
2020-07 \\ Colleret, Maxime et Yves Gingras \\ "L'intelligence artificielle au Québec : un réseau tricoté serré " \\ 2020-06 Gingras, Yves, Jean-Hugues Roy, Kristoff Talin et Caroline St-Louis \\ "Connaissances et représentations des sciences chez les artisans francophones canadiens et \\ québécois de l'information" \\ 2020-05 \\ Khelfaoui, Mahdi et Yves Gingras \\ "L'effet SIGAPS : La recherche médicale française sous l'emprise de l'évaluation comptable " \\ 2020-04 \\ Josquin Debaz, Yves Gingras, Jérôme Lamy, Arnaud Saint-Martin, Émilien Schultz et Jeremy K. Ward \\ "Academic debates and the complexity of the hydroxychloroquine controversy" \\ 2020-03 \\ Khelfaoui, Mahdi et Yves Gingras \\ "Branding Scholarly Journals: Transmuting Symbolic Capital into Economic Capital " \\ 2020-02 \\ Dandurand, Guillaume , François Claveau, Jean-François Dubé et Florence Millerand \\ "Al Like Any Other Technology: Social Dynamics of Expectation and Expertise \\ of a Digital Humanitarian Innovation " \\ 2020-01 Talin, Kristoff et Yves Gingras \\ $"+$ de religion $=-$ de science $"$ \\ 2018-01 \\ Carlier, Denis \\ "Numérisation et analyse de documents" \\ 2015-01 Dias Da Silca, Patricia et Lorna Heaton \\ "Citizens, amateurs, volunteers: Conceptual struggles in studies of citizen science " \\ 2014-03 \\ Hanel, Petr \\ "Is China catching-up human health-related applications of biotechnology ? " \\ 2014-02 \\ Maroy, C., P. Doray, M. Kabore \\ "La politique de financement des universités au Québec à l'épreuve du "Printemps érable "» \\ 2014-01 Bastien, N., P. Chenard, P. Doray, B. Laplante \\ "Économie, société et éducation: I'effet des droits de scolarité sur l'accès aux études universi- \\ taires au Québec et en Ontario " \\ 2013-03 Hanel, Petr, Jie He, Jingyan Fu, Jorge Niosi et Suzan Reid \\ "A romance of the three kingdoms and the tale of two cities: the role and position of the bio- \\ technology industry cluster in Guangdong province, China " \\ 2013-02 \\ Gauthier, Elisabeth, Gale E. West et Anne-Marie Handfield \\ "Why do humans need to do battle? Social representations of alternative pest control ap- \\ proaches" \\ 2013-01 \\ Bastien, Nicolas, Pierre Chenard, Pierre Doray et Benoit Laplante \\ "L'accès à l'université: le Québec est-il en retard?"
}


Le CIRST est, au Canada, le principal regroupement interdisciplinaire de chercheurs dont les travaux sont consacrés à l'étude des dimensions historiques, sociales, politiques, philosophiques et économiques de l'activité scientifique et technologique.

Nos travaux visent l'avancement des connaissances et la mise à contribution de celles-ci dans l'élaboration et la mise en œuvre des politiques ainsi que dans la résolution des problèmes de société qui présentent des dimensions scientifiques et technologiques.

Le CIRST rassemble une quarantaine de chercheurs provenant d'une dizaine d'institutions et d'autant de disciplines, telles que I'histoire, la sociologie, la science politique, la philosophie, les sciences économiques, le management et les communications.

Le CIRST fournit un milieu de formation par la recherche à de nombreux étudiants de cycles supérieurs dans les domaines de recherche de ses membres. Créé en 1986, il est reconnu par l'Université du Québec à Montréal, I'Université de Montréal, l'Université Laval, Polytechnique et I'Université de Sherbrooke. Le CIRST est un regroupement stratégique du Fonds de recherche du Québec-Société et culture. 